

\section{Philosophical Problems in Contemporary Art Criticism: Objectivism, Poststructuralism, and the Axiom of Authorship}

It is absurd to hold that a man ought to be ashamed of being unable to defend himself with his limbs, but not of being unable to defend himself with rational speech, when the use of rational speech ... can confer the greatest of benefits ... Before some audiences, not even the possession

of the exactest knowledge will make it easy for what we say to produce conviction ... [Here] we must be able to employ persuasion, just as deduction can be employed, on opposite sides of a question - not in order that we may in practice employ it in both ways (for we must not make people believe what is wrong), but in order that we may see clearly what the facts are, and that, if another man argues unfairly, we on our part may be able to confute him.

- Aristotle ([350 BC] 1995: 4622-4623)

\section{Introduction}

In response to questions regarding one's reasons for practicing a martial art, one of the most common answers given is self-defense, the desire to equip oneself with the tools necessary to live confidently in the world ready for whatever physical attack may come. By contrast, in response to questions regarding one's reasons for practicing philosophy, self-defense is rarely given as an answer. The precedent for philosophy-as-self-defense is the work of Aristotle, for whom philosophical argument was precisely a form of combat. ${ }^{1}$ In more recent history, the most prominent practitioner of philosophy-as-self-defense has been Ayn Rand. In her fiction writing, 
most notably in The Fountainhead and Atlas Shrugged, but more extensively in her later nonfiction writing, Rand developed a philosophical system she called Objectivism. Following Aristotle, Objectivism was intended by Rand to serve as a method of self-defense, as a means to equip oneself with the tools necessary to live confidently in the world ready for whatever intellectual attack may come.

In an address given, fittingly enough, at West Point to the graduating class of 1974, Rand maintained that one must study even philosophical ideas that seem to be "blatantly false," to "make no sense," and to "bear no relation to real life," for if one fails to understand such ideas, one is "vulnerable to the worst among them" (Rand [1974a] 1982: 7-8). Connecting philosophy to military combat, Rand elaborated:

In [the military], you know the importance of keeping track of the enemy's weapons, strategy, and tactics - and of being prepared to counter them. The same is true in philosophy: You have to understand the enemy's ideas and be prepared to refute them, you have to know his basic arguments and be able to blast them (Rand [1974a] 1982: 7$8)$.

Broadly speaking, Objectivism represents a comprehensive view of existence, what Rand liked to call "a philosophy for living on Earth" (Rand [1974a] 1982: 10). She broke Objectivism down into five major branches - metaphysics, epistemology, ethics, politics, and aesthetics - though she stressed that the first three branches were of fundamental importance. As she explained with reference to politics (and this explanation applies equally to aesthetics): 
[Objectivism] does not regard politics as a separate or primary goal - that is, as a goal that can be achieved without a wider ideological context. Politics is based on three other philosophical disciplines: metaphysics, epistemology, and ethics - on a theory of man's nature and of man's relationship to existence. It is only on such a base that one can formulate a consistent political theory and achieve it in practice ... [Thus,] Objectivism advocates certain political principles ... as the consequence and the ultimate practical application of its fundamental philosophical principles (Rand 1962: 1).

This is an important point. Moreover, it is a valid point. Yet, it does not explain the comparative lack of interest shown by Objectivists - and even by Rand herself - in defending aesthetics or applying Objectivist principles to aesthetics. ${ }^{2}$ And this neglect is one of the many reasons why the realm of contemporary art criticism is little more than an intellectual wasteland. The force that has for decades been destroying art criticism is a force that Rand once had occasion to go up against: The force of the unreadable. An unreadable book or essay, as explicated by Rand, "does not count on men's intelligence, but on their weaknesses, pretensions, and fears"; it "is not a tool of enlightenment, but of intellectual intimidation"; and it "is not aimed at the reader's understanding, but at his inferiority complex" (Rand [1973a] 1982: 117). Strangely, the unreadable seemed to Rand to be an unstoppable force. For all her optimism, when it came to the force of the unreadable, she did not appear to have much hope:

Within a few years [of the publication of an unreadable book or essay], commentators will begin to fill libraries with works analyzing, "clarifying," and interpreting its 
mysteries. Their notions will spread all over the academic map, ranging from the appeasers, who will try to soften [its] meaning - to the glamorizers, who will ascribe to it nothing worse than their own pet inanities - to the compromisers, who will try to reconcile its theory with its exact opposite - to the avant-garde, who will spell out and demand the acceptance of its logical consequences. The contradictory, antithetical nature of such interpretations will be ascribed to [its] profundity - particularly by those who function on the motto: "If I don't understand it, it's deep." The students will believe that the professors know the proof of [its] theory, the professors will believe that the commentators know it, the commentators will believe that the author knows it - and the author will be alone to know that no proof exists and that none was offered. Within a generation, the number of commentaries will have grown to such proportions that the original [unreadable book or essay] will be accepted as a subject of philosophical specialization, requiring a lifetime of study - and any refutation of [its] theory will be ignored or rejected if unaccompanied by a full discussion of the theories of all the commentators, a task which no one will be able to undertake (Rand [1973a] 1982: 117118).

Against the appeasers, the glamorizers, the compromisers, and the avant-garde stands the "intelligent man." Far from valiantly defending reason, though, the intelligent man, on Rand's account, will simply reject the unreadable, "refusing to waste his time on untangling what he perceives to be gibberish" (Rand [1973a] 1982: 117). Is it any wonder that the unreadable has proceeded, unabated, to permeate the philosophy of art to the point where "the philosophy of art" is merely another name for "the unreadable"? If "the man able to refute its arguments will not 
(unless he has the endurance of an elephant and the patience of a martyr)" (Rand [1973a] 1982:

117), then what hope is there for aesthetics? What is there for scholars to do but pray for a miracle?

In Atlas Shrugged, John Galt addresses the last of his words to the "heroes who might still be hidden in the world, those who are held prisoner not by their evasions but by their virtues and their desperate courage" (Rand 1957: 1060). By the same token, this essay is addressed to the heroes still hidden in the field of art criticism, those who want but who are unsure of how to formulate a rational philosophy of art. In accordance with the sentiment that "it is impossible to predict the time of a philosophical Renaissance," Rand once expressed the thought that the most one can do is "define the road to follow" (Rand [1969] 1975: 115). I hope that this essay may, at the very least, serve as a helpful signpost on the road to an Objectivist aesthetics. In what follows, I will provide a practical example of such an elephantine endeavor by refuting the philosophy of art promulgated by proponents of the philosophical school of poststructuralism propaedeutic to the construction of an Objectivist aesthetics.

Before proceeding to refute the aesthetic principles of poststructuralism, however, I would be remiss vis-à-vis "Rand's Razor"3 if I did not first clarify my own aesthetic principles. The aesthetic principles on which my conception of an Objectivist aesthetics is based proceed from what I call the axiom of authorship. An axiom, Rand explained, is "a statement that identifies the base of knowledge and of any further statement pertaining to that knowledge, a statement necessarily contained in all others, whether any particular speaker chooses to identify it or not." Furthermore, an axiom "defeats its opponents by the fact that they have to accept it and use it in 
the process of any attempt to deny it" (Rand 1957: 1040). The metaphysical axiom at the heart of Objectivism is existence exists, the propositional form of which is $A$ is $A$. The axiomatic concepts that result from this axiom are existence, identity, and consciousness; they follow from the axiom and its two corollaries: First, that something exists which one perceives, and second, that one exists possessing consciousness, consciousness being the faculty of perceiving that which exists. To simplify: Existence is Identity, Consciousness is Identification (Rand 1957: 1016).

In an Objectivist aesthetics, then, authorship is an artistic axiom since, by speaking about art at all, one is conceding the axiom of authorship, for art is a product of creation and creation presupposes an entity capable of and responsible for creating. To this end, the aesthetic principles to which the axiom of authorship gives rise and on which my conception of an Objectivist aesthetics is based are the following:

1) The Objectivity Principle - An artwork exists independent of the act of reading/listening/viewing (for without the artwork, there would be nothing to read/listen to/view) and an artwork is what it is independent of the act of interpretation (for without the artwork, there would be nothing to interpret).

2) The Identity Principle - An interpretation of an artwork can be considered valid only if it adequately explains what the artwork is and why the artwork is the way it is. 
3) The Causality Principle - An artwork is a made object; thus, explanations as to what an artwork is and why an artwork is the way it is must consider the intentions of the person who created the artwork, i.e., its author.

These three aesthetic principles seem eminently straightforward if not self-evident. Unfortunately, despite the considerable boon to the analysis of art provided by the axiom of authorship, there appeared in the 1960s a plethora of misguided "radicals" keen to challenge the "authority" of the author and to institute a new model of criticism. As one of the lone voices of reason then working in the field of literary theory, E.D. Hirsch maintained that it was essential for philosophers of art to not only understand the epistemological conditions of possibility for the "heavy and largely victorious assault on the sensible belief that a text means what its author meant" that is the legacy of 20th Century aesthetics, but even more importantly, "to determine how far the theory of [textual] autonomy deserves acceptance" (Hirsch 1967: 1-2). The same is true today. However, in the interest of conceptual clarity, I would argue, pace Hirsch, that what is essential is to understand that the very notion of "textual autonomy" is nonsense. In any rational philosophy of art, the concept of authorship must be the conceptual alpha and omega. Yet, if the history of $20^{\text {th }}$ Century aesthetics is any indication, no concept has been the target of more, or more violent, attacks than the concept of authorship.

Challenges to author-based criticism have come from diverse individuals from a variety of academic and non-academic backgrounds, but because its contemporaneity, its extremism, and its considerable influence make for a troubling combination, I will focus exclusively in this essay on the philosophical school of poststructuralism. More specifically, I will interrogate the 
influential work of poststructuralist avatars Roland Barthes and Jacques Derrida to the end of proving that they both fail to make a prima facie case against authorship. ${ }^{4}$ Before doing so, however, I should emphasize that my engagements with Barthes and Derrida will not merely be critical engagements; more to the point, they will be polemical engagements. Since I do not believe in pulling my punches, this essay will proceed according to what Simon Critchley has referred to as an "economy of viciousness" (Critchley 2007: xiv). To Critchley's mind, polemics are an "intellectually healthy" activity with "sharp philosophical edges" (Critchley 2007: xiv). In a similar vein, Stephen Prince has encouraged "spirited opposition" not only because it can serve as a "measure of vitality" with respect to a given field but because "the flash and fire of [polemics] can illuminate [a] field's basic and often unexamined assumptions and methods, its very history and traditions" (Prince 1992: 49). This is what D.N. Rodowick calls "the value of being disagreeable" (Rodowick 2013): Given that an argument is "a public and social event open to conversation and debate, agreements and disagreements," there is the potential, through polemical engagements, of "transform[ing] the terms of debate, the language in which it is expressed, and the nature of the epistemological and axiological commitments that have been entered into" (Rodowick 2015: 79).

Transforming the terms of debates in the philosophy of art and encouraging philosophers of art to transform their epistemological and axiological commitments are two of the most pressing issues facing the practice of art criticism. However, given the "crushing weight of the philosophical wreckage under which generations [of scholars] have been brought up" (Rand [1969] 1975: 94), it is clear that, to precipitate such a seismic philosophical shift, polite conversation will not suffice. Stanley Cavell once opined that "lines are to be drawn, or what's a 
conversation for?" (Cavell 1981: 227). This is the polemical position from which I will now commence with the drawing of lines.

\section{Roland Barthes and the Attempted Murder of the Author}

In 1967, Roland Barthes published a short polemic entitled “The Death of the Author." Despite the fact that Barthes' call-to-arms is made up of conspicuous logical fallacies, contradictions, and equivocations - to say nothing of its toxic Nietzschean "morality" - "The Death of the Author" still holds sway in a number of academic circles half a century later. In fact, in the years since the publication of this extraordinarily influential essay, the author has been disavowed in virtually every critical and theoretical context across the humanities. ${ }^{5}$ In an effort to restore the concept of authorship to its rightful place as the conceptual alpha and omega in the philosophy of art, I will subject Barthes' influential essay to a sustained interrogation in which I will identify and condemn the logical and moral shortcomings of what I will hereafter refer to as Barthes' attempted murder of the author. Ultimately, I will argue that Barthes' failure in "The Death of the Author" is not, strictly speaking, a failure of knowledge, but rather, in Cavell's terminology, a failure of acknowledgment:

Acknowledging is not an alternative to knowing ... In incorporating, or inflecting, the concept of knowledge, the concept of acknowledgment is meant, in my use, to declare that what there is to be known philosophically remains unknown not through ignorance ... but through a refusal of knowledge, a denial or a repression of knowledge, say even a killing of it (Cavell [1986a] 1988: 51). 
In one sense, then, "The Death of the Author," inasmuch as it represents a failure of logic and morality, may seem irrelevant (or anathema) to the construction of an Objectivist aesthetics. In another sense, however, its logical and moral shortcomings may be considered instructive and, as such, indispensable. This latter sense aligns with the philosophical practice of J.L. Austin, who maintained that identifying and mastering techniques for "dissolving philosophical worries" is a crucial skill in the realm of philosophical argumentation; as he observed, "there is nothing so plain boring as the constant repetition of assertions that are not true, and sometimes not even faintly sensible," and if the cultivation of philosophical habits conducive to rational thought allows for nonsensical assertions (such as those of which "The Death of the Author" is composed) to be dissolved, "it will be all to the good" (Austin 1962: 5). ${ }^{6}$

Unfortunately, due to the schizophrenic sloppiness with which Barthes presents his argument in "The Death of the Author," discerning what exactly he is arguing at any given moment and how the entire argument hangs together is no easy feat (never mind dissolving the philosophical worries therein). In fact, even at this preliminary stage of my critique, there has already been a misstep, for to speak of the argument in "The Death of the Author" implies that it consists of one argument. To be more precise, "The Death of the Author" consists of two arguments. And, as if this is not confusing enough, within each of these arguments, Barthes vacillates between an extreme version and a moderate version.

On the one hand, in what I will refer to as the production argument, Barthes calls for a paradigm shift in artistic production. In the extreme version, writing calls for a "prerequisite 
impersonality" (how writing "calls for" this "impersonality," Barthes does not say). In the moderate version, writing does not "call for" a prerequisite impersonality, but the author is nevertheless supposed to approach art impersonally and to intentionally suppress his "authority" so as to allow language to work its magic (why and by whom the author is "supposed" to approach art impersonally, Barthes does not say). Even though the terms of the extreme version and the moderate version are different, they are both designed to bring art to the Barthesian "utopia" in which "it is language which speaks, not the author" (Barthes [1967] 1977: 143).

On the other hand, in what I will refer to as the reception argument, Barthes also calls for a paradigm shift in artistic reception. Ironically, the very existence of the reception argument proves that the extreme version of the production argument is nonsense. After all, if language were the only volitional entity in production (i.e., if the author did not have a role to play in the first place), then there would be no need to make an argument for reception based on the premise that language is the only volitional entity in production. It would be self-evident. Thus, both the extreme version and the moderate version of the reception argument are related to the moderate version of the production argument.

The moderate version of the reception argument follows from the implementation of the moderate version of the production argument: Once art has been transformed into an arena wherein authors willingly submit to language, readers may thus dispense with the notion of deciphering art and may concern themselves solely with disentangling it. ${ }^{7}$ However, in the event that there are authors who refuse to submit to language, then the extreme version of the reception argument is deployed. In the extreme version, the "revolutionary" reader is supposed to "refuse 
God and his hypostases - reason, science, law" and forcibly remove the author (why and by whom the reader is "supposed" to "remove" the author, Barthes does not say) (Barthes [1967] 1977: 147).

Fueling these two arguments is a putative quest to "liberate" art from the "tyranny" of the author, after which "the people" may rejoice in the jouissance of the "infinitely polysemous" text. Barthes puts on the airs of Robin Hood, but the key point to be made is that this is merely misdirection. Operating beneath his alleged quest for liberation is a far more sinister project (which he would later refer to as the construction of a "hedonistic aesthetics" $"$ ) the end result of which is out-and-out murder. Of course, Barthes does not explicitly endorse (at least not initially) the murder of the author. Instead, he proceeds as if his arguments are strictly, even peaceably, logical. Thus, the first problems to arise in "The Death of the Author" are relatively straightforward problems of logic; in both the production argument and the reception argument, and in both the extreme versions and the moderate versions of each, Barthes relies at every turn on two logical fallacies.

The first fallacy is the fallacy Rand terms concept stealing, whereby one denies the primacy of a putatively invalid concept (e.g., authorship) and then asserts the primacy of a derivative concept (e.g., art) (Rand 1957: 1039-1040). The second fallacy is the fallacy Rand terms package dealing, whereby one attempts to integrate into a unified conceptual whole, or package, a series of contradictory concepts/premises (e.g., conflating the author and God) (Rand [1973b] 1982: 28-29). These two fallacies are at work in both of the arguments running throughout "The Death of the Author." According to the production argument, Barthes claims that artistic production is 
not (in the extreme version) or should not be (in the moderate version) a matter of people "expressing themselves," but rather, a matter of allowing language to "express itself" through them. Theoretically, Barthes formulates the extreme version of the production argument in the following manner:

Enunciation is an empty process, functioning perfectly without there being any need for it to be filled with the person of the interlocutors ... Language knows a "subject," not a "person," and this subject, empty outside of the very enunciation which defines it, suffices to make language "hold together" (Barthes [1967] 1977: 145).

Applying this nonsensical theoretical model to actual artistic practice, Barthes outlines the process as follows:

The modern scriptor can thus no longer believe, as according to the pathetic view of his predecessors, that this hand is too slow for his thought or passion ... On the contrary, the hand, cut off from any voice, borne by a pure gesture of inscription (and not of expression), traces a field without origin - or which, at least, has no other origin than language itself (Barthes [1967] 1977: 146).

These formulations lead to the major contradiction that contributes to the collapse of the production argument. In the moderate version of the production argument, Barthes tries to preserve the concept of intention without the concepts of identity or consciousness. This is a straightforward case of concept stealing, for intention presupposes an entity capable of intending, 
which in turn presupposes the concepts of identity and consciousness. In the extreme version of the production argument, however, Barthes shifts from concept stealing to package dealing, anthropomorphizing capital-L "Language" and then proceeding to deny that either consciousness or intention are attributable to human beings, thus leaving Language as the only "conscious" entity possessing volition and thus capable, by some unexplained supernatural means, of intending. ${ }^{9}$

Interestingly, Barthes opts for a positive conception of the "pure" functionality of Language akin to the popular (mis)reading of the Hegelian "Cunning of Reason" as opposed to the negative conception of the insidiousness of language often attributed to Jacques Lacan. ${ }^{10}$ In either case, it is Language that is posited as possessing volition and thus capable of intending, although whether it is Language that possesses volition while human beings do not, as in the extreme version, or whether both Language and human beings possess volition but human beings are to cede their volition to Language, as in the moderate version, both pictures of language are nonsense. ${ }^{11}$ Undeterred, Barthes astonishingly tries to bolster the extreme version of the production argument with reference to ordinary language philosophy as if it confirms his thesis when, in point of fact, ordinary language philosophy is its antithesis (Barthes [1967] 1977: 145146). Cavell provides a clear description of the perspective of ordinary language philosophy on language and communication, a description which illuminates how fundamentally it contradicts Barthes' antihumanist model:

There must, [in language], be reasons for what you say ... if what you say is to be comprehensible. We can understand what the words mean apart from understanding why 
you say them, but apart from understanding the point of your saying them, we cannot understand what you mean ... The emphasis is [thus] on the fact that [expressions] are said (or, of course, written) by human beings, to human beings, in definite contexts, in a language they share: hence the obsession with the use of expressions (Cavell 1979: 206).

The final piece of corroborating evidence against the extreme version of the production argument is, ironically, Barthes' own critical practice. When he has occasion to lament the "sway of the author" and how powerful it has proven to be, he claims that "certain writers have long since attempted to loosen it" (Barthes [1967] 1977: 143). To Barthes' mind, writers such as Stéphane Mallarmé, Paul Valéry, and Marcel Proust intended in their work - and, as far as Barthes was concerned, followed through successfully on their intentions - to problematize in various ways and to varying degrees the concept of authorship. Counter-intuitive and self-destructive though this intention may be, the fact remains that Barthes' assessment of these men's respective work as attempts to challenge the sway of the author relies for its persuasiveness on intentions imputed to Mallarmé-as-author, Valéry-as-author, and Proust-as-author. ${ }^{12}$

Having invalidated the extreme version of the production argument, the moderate version, where the author accedes to the "will" of Language, may still seem viable. The reason Barthes believes Mallarmé stands out is because, as Barthes puts it, he recognized "the necessity to substitute language itself for the person who until then had been supposed to be its owner" (Barthes [1967] 1977: 143). ${ }^{13}$ There are a number of questions that seem worth asking here: How did Mallarmé recognize this "necessity"? How does one "substitute language itself" for the "person"? Why is it necessary to do so? Beyond these obvious questions, a less obvious question is also hovering in 
the background: Who benefits from such a substitution? These questions are meant to underscore the fact that "The Death of the Author" does not merely exemplify a corruption of logic. Even more important to recognize, "The Death of the Author" exemplifies a corruption of morality.

Early in "The Death of the Author," Barthes observes that the value of the author (and thus of logic and reality) is related to "capitalist ideology, which has attached the greatest importance to the 'person' of the author" (Barthes [1967] 1977: 143). He is absolutely correct in this observation, which implies that the moral foundation of capitalism is the individual and his rights. Where he is wrong is in thinking this is a knock against either authorship or capitalism (or logic, or reality). On the basis of this observation and the implication that it indicates an error, it becomes clear that the link between the moderate version of the production argument and the moderate version of the reception argument is the morality of altruism. In the moral register, altruism is marshaled to oppose individualism, while, in the political register, Marxism is marshaled to oppose capitalism. ${ }^{14}$

According to Barthes' altruistic aesthetic model, the author must sacrifice his individuality for the "good" of "the people." Barthes states that "as soon as a fact is narrated ... outside of any function other than that of the very practice of the symbol itself ... the author enters into his own death" (Barthes [1967] 1977: 142). If, in Barthes' altruistic aesthetics, it is necessary for the author to "substitute language itself" for his "person" - the moral/political implication of which is that the individual does not have the right, is not free, to exist for himself - and if, in doing so, he "enters into his own death" - the moral/political implication of which is that the individual must sacrifice himself for the sake of others - then what is necessary in Barthes' aesthetics on 
the part of the author is suicide. ${ }^{15}$ Worse yet: What happens if Barthes comes across an author who rejects the morality of altruism and who refuses to commit suicide? What happens if he comes across an author who instead lives according to a morality of individualism and who insists on the right to and the freedom of self-expression?

In the event the extreme version of the production argument, in which language is a volitional entity that uses helpless and mindless human beings to produce texts by ineffable means, is invalid - which, as I hope to have convincingly demonstrated, it is - and if the conjunction of the moderate versions of the production argument and the reception argument, in which the author is required to sacrifice his individuality and commit suicide for the good of the people who may then do with the remaining text qua alms whatever they wish, is also invalid - which, as I hope to have convincingly demonstrated, it is - Barthes still needs a way to ensure that he is able to indulge in the jouissance of the infinitely polysemous text. In these circumstances, if the author refuses to commit suicide on Barthes' command, then Barthes is left with only one option: Murder.

Rand once observed that there are only two means by which people can deal with one another, logic or force, and that irrational and immoral people who cannot win by means of logic invariably resort to the use of force (Rand [1966] 1970: 66). Even though Rand made this observation before Barthes wrote "The Death of the Author," it nevertheless serves as a perfect description of the path taken by Barthes over the course of his essay. Initially, Barthes attempts to disguise the murderous nature of his essay. To prove that he is not committing murder, he attempts to show, on logical grounds, that there simply is no author to be murdered: 
Did [the author] wish to express himself, he ought at least to know that the inner "thing" he thinks to "translate" is itself only a ready-formed dictionary ... Succeeding the Author, the scriptor no longer bears within him passions, humors, feelings, impressions, but rather this immense dictionary from which he draws a writing that can know no halt (Barthes [1967] 1977: 146-147). ${ }^{16}$

Barthes' substitution of a "ready-formed dictionary" for the "self" allegedly "expressed" by the author signals the radicalization of a more modest argument of his from Writing Degree Zero. In this early text, Barthes begins from the premise that art has its roots "in the depths of the author's personal and secret mythology" (Barthes [1953] 2012: 10). Unfortunately, Barthes' explication of authorial intention is steeped in mysticism; he alternatively conceives authorial intention as "the writer's 'thing"” (Barthes [1953] 2012: 11), an "occult aspect" of his "carnal structure" that is "locked within [his] body" (Barthes [1953] 2012: 12), and a "miracle" of "transmutation" indicating a "supra-literary operation which carries man to the threshold of power and magic" (Barthes [1953] 2012: 12). Given the mercuriality of Barthes' conception of authorship and how little time he invests in articulating its logic, it is hardly surprising that he proceeds to vitiate the concept by claiming that Language, insofar as it "remains full of the recollection of previous usage" and consists of signs with "a second-order memory which mysteriously persists in the midst of new meanings," invariably "drowns the sound" of the author's self-expression (Barthes [1953] 2012: 16-17). 
While Barthes' conception of Language in "The Death of the Author" is clearly carried over from Writing Degree Zero, his conception of authorship is demonstrably different. In Writing Degree Zero, Barthes grants the author a (limited) degree of autonomy. In "The Death of the Author," however, Barthes begins from the premise that art "is the destruction of every voice, of every point of origin" (Barthes [1967] 1977: 143). Of course, recalling my point about the reception argument invalidating simply by virtue of its existence the extreme version of the production argument, if it were true that art is now/always was as destructive as Barthes claims, then insisting that authors sacrifice themselves in the spirit of altruism would be useless if not inconceivable. ${ }^{17}$ As if sensing the insufficiency of his precarious yoking together of the extreme and moderate versions of the production argument with the moderate version of the reception argument, Barthes resorts in the end to the extreme version of the reception argument. This entails a shift on Barthes' part from speaking of the author being (naturally) succeeded (by the scriptor) to being (forcibly) removed (by the reader):

To give a text an author is to impose a limit on that text, to furnish it with a final signified, to close the writing. Such a conception suits criticism very well, the latter then allotting itself the important task of discovering the author ... [and] when the author has been found, the text is "explained" - victory to the critic ... It is [therefore] derisory to condemn the new writing in the name of a humanism hypocritically turned champion of the reader's rights ... We are now beginning to let ourselves be fooled no longer by the arrogant antiphrastical recriminations of good society in favor of the very thing it sets aside, ignores, smothers, or destroys; we know that, to give writing its future, it is 
necessary to overthrow the myth: the birth of the reader must be at the cost of the death of the author (Barthes [1967] 1977: 147-148).

This argument is the logical endpoint for "The Death of the Author," its toxic "morality" culminating in unadulterated murder. There are so many things wrong with this passage that I will enumerate them in list form:

1) The notion of giving a text an author is a package deal predicated on the author/God conflation. ${ }^{18}$ Authors are not given, they are acknowledged. Moreover, Barthes goes so far in this passage as to actually assume the role of God. At various points in "The Death of the Author," Barthes makes references to refusing God and to anti-theological reading practices which reject the "theological" meaning of the Author-God (Barthes [1967] 1977: 146-148). By virtue of this passage, however, it is clear that what draws Barthes' wrath is not the concept of God, but rather, the fact that he is not God. It is hubris, pure and simple, and following the "logic" of "the Lord giveth and the Lord taketh away," Barthes-as-God assumes the position of being able to give to or take away from a text the author. The lunacy has here reached its apogee. ${ }^{19}$

2) Readers cannot impose limits on texts. The only choice readers have is to (a) read within the (author's) limits or to (b) read beyond the (author's) limits. In short: Writers write, readers read. ${ }^{20}$

3) By putting "explained" in quotes, Barthes is implying that, once the author is discovered, there is no more work to be done by criticism. This is a reductive conception of criticism and, quite simply, another straw man. 
4) To imply that respecting the role of the author in art (which is to say, respecting the role of the human in the world) is not a humanist position while committing violence against the author and, by extension, art (which is to say, lashing out against humanity and the world) is a humanist position is an egregious reversal of the facts of reality and the only authentic display of hypocrisy and antiphrasis. ${ }^{21}$

For as intolerably affronting as these many crimes against logic and morality are, the greatest offense committed in this heinous passage is the construction of art as a violent arena in which authors and readers are pitted against one another and forced into gladiatorial combat. That Barthes' hedonistic aesthetics ultimately reaches this point of out-and-out murder and mayhem should not be a surprise given its irrational and immoral premises, and in particular given its rejection of a capitalist model of artistic production, which, in Objectivist terms, may be described as follows:

[The author] contributes the most to [the artistic community] but gets nothing except his material payment, receiving no intellectual bonus from others to add to the value of his time. [The reader] who, left to himself, would [be without art,] contributes nothing ... Such is the nature of the "competition" between [author and reader]. Such is the pattern of "exploitation" for which you have damned [the author]. Such was the service [authors] were glad and willing to give. What did [they] ask in return? Nothing but freedom ... Such was the price [they] asked, which you chose to reject as too high ... You decided that you had a right to your [experience] but [they] had no right to [their expression] ... 
You did not care to [live] in terms of intelligence - you are now [living] in terms of brutality (Rand 1957: 1065).

As Barthes' hedonistic aesthetics reduces art to a pile of ash and humans to violent, mindless savages, there is an obvious question that remains: Is there a moral alternative? Is there a conception of art that does not lead to death and destruction? Fortunately, there is. The moral alternative to Barthes' hedonistic aesthetics is a conception of art which is not predicated on looting, on demanding and taking the unearned, but on trading. Trade, Rand states in no uncertain terms, is "the moral symbol of respect for human beings" (Rand 1057: 1022), and she provides a practical demonstration of art as trade and author and critic as traders in the following passage:

I do not care to be admired causelessly, emotionally, intuitively, instinctively - or blindly. I do not care for blindness in any form, I have too much to show - or for deafness, I have too much to say. I do not care to be admired by anyone's heart - only by someone's head. And when I find a customer with that invaluable capacity, then [art] is a mutual trade to mutual profit ... [Hence,] the payment I demand ... [is not merely] your enjoyment ... [but more importantly] your understanding and the fact that your enjoyment was of the same nature as mine, that it came from the same source: from your intelligence, from the conscious judgment of a mind able to judge my work by the standard of the same values that went to [create] it - I mean, not the fact that you felt, but that you felt what $I$ wished you to feel, not the fact that you admire my work, but that you admire it for the things $I$ wished to be admired (Rand 1957: 782). 
The problem in "The Death of the Author" is that the ideas of art as trade and author and critic as traders are anathema to Barthes. Art, according to Barthes' moral code, is a matter of conquest, and he will be damned if he will allow himself to be conquered by any author. As Rand makes clear, though, art and its criticism come from the same source, which is not a source of victory or defeat, but rather, "from an inviolate capacity to see through one's own eyes - which means: the capacity to perform a rational identification - which means: the capacity to see, to connect, and to make what had not been seen, connected, and made before" (Rand 1957: 783). A truly moral criticism does not encourage critics to commit violence against the authors who have demonstrated their capacity to see through their own eyes and communicate their philosophies of life in their art; rather, a moral criticism encourages the mutuality, the connection, the harmony, the acknowledgment between critic and author whereby a critic is moved to respond to an author whose philosophy of life resonates (for better or worse) with his own. ${ }^{22}$

The critic who "believes in" (i.e., who values) the author is, in Barthes' estimation, a pathetic fraud; yet, the critic he envisions - the pirate who pillages and plunders art indifferent to (or, worse yet, gleeful at the prospect of) its destruction - is to be considered a moral ideal? This inversion of morality is the logical result of an irrational moral code that values the murder of the author as the height of critical nobility, the destruction of art as a demonstration of critical brilliance, and death as the standard of life. This inversion of morality is equally the logical proof of Barthes' guilt, for if a moral crime is, as Rand defines it, the attempt to create, through words or actions, an impression of the irrational - and thereby shake the concept of rationality in others 
(Rand 1957: 488) - then Roland Barthes is a moral criminal whom scholars have been aiding and abetting for half a century.

\section{Jacques Derrida and the Failure to Communicate}

Over the course of a historical survey of philosophy, Rand identifies two figures - the man of faith and the man of force - that stand out as "philosophical archetypes, psychological symbols, and historical reality":

As philosophical archetypes, they embody two variants [of mysticism]. As psychological symbols, they represent the basic motivation of a great many men who exist in any era, culture, or society. As historical reality, they are the actual rulers of most of mankind's societies, who rise to power whenever men abandon reason. The essential characteristics of these two remain the same in all ages: Attila, the man who rules by brute force, acts on the range of the moment, is concerned with nothing but the physical reality immediately before him, respects nothing but man's muscles, and regards a fist, a club, or a gun as the only answer to any problem - and the Witch Doctor, the man who dreads physical reality, dreads the necessity of practical action, and escapes into his emotions, into visions of some mystic realm where his wishes enjoy a supernatural power unlimited by the absolute of nature (Rand 1961: 10).

To shift from the writings of Roland Barthes to those of Jacques Derrida is, on Rand's terms, to shift from an Attila to a Witch Doctor, from a thinker who traffics primarily in brute force to a 
thinker who traffics primarily in mystic faith. Of course, faith and force are not mutually exclusive. There is an Attila in every Witch Doctor and a Witch Doctor in every Attila. Indeed, Rand points out that "both feel secretly inadequate to the task of dealing with existence" and hence "come to need each other" (Rand 1961: 14). Nevertheless, the distinction between an Attila and a Witch Doctor is worth preserving, for it speaks to the vicissitudes of philosophical failure beyond sheer evil.

In an insightful consideration of the role of ethics in philosophy, David Kelley stresses that moral judgments in philosophy are only valid if they are supported "by observing how a person thinks, by attending to his reasoning rather than his conclusions in isolation":

In judging rationality, we are concerned with the process by which a person arrived at his ideas. We cannot observe this process directly; we cannot literally see an act of thought or evasion in someone else's mind. But the process is revealed in numerous ways - by the kinds of connections a person makes, by his openness to evidence, by his general demeanor. One may observe how a person deals with the objections one raises, how willing he is to examine the issues in depth, to lay out his reasons for his position. One may observe whether a person gets angry when his position is challenged, or relies on the cruder sorts of fallacies such as ad hominem or appeal to emotion, or dodges from one issue to another in response to objections. These are all signs of non-objectivity. They tell one that some motive is at work other than a desire to grasp the facts (Kelley [1990] 2000: 56). 
In line with Rand's acknowledgment that "truly and deliberately evil men are a very small minority" (Rand [1966] 1989: 39), Kelley considers it irresponsible to condemn all who err in philosophy as irredeemably evil. Because, as Rand went to great lengths to elucidate, the activity of thinking is volitional rather than automatic and subject to error rather than infallible, "it is perfectly possible to commit errors of thinking because one has not fully mastered the relevant skills, or because some complexity in the subject matter makes it difficult to apply the methods properly" (Kelley [1990] 2000: 51-52). After all, the philosophical problems with which this essay is concerned are problems that have occupied the minds of countless thinkers. To assume that mistakes made along the way invariably indicate immorality would be downright silly.

This difference between evil and error is important to stress here because this is precisely the difference that I maintain separates Barthes and Derrida. In the previous section, I argued that Barthes was a moral criminal. In this section, I will argue that Derrida is a moral coward. Unlike Barthes, who was driven by a Nietzschean "will to power," that which drives Derrida is what Cavell calls a fantasy of necessary inexpressiveness, a fantasy "in which I am not merely unknown but in which I am powerless to make myself known" (Cavell 1979: 351). It was against powerlessness that Barthes was fighting in "The Death of the Author," it was the very idea of being powerless that frightened Barthes and fueled his irrational and immoral quest for omnipotence. Derrida, by contrast, finds solace in the idea of powerlessness as a (paradoxically powerful) force capable of annulling his responsibility and accountability as a human being alive in and to the world. Discernible in the fantasy of necessary inexpressiveness is what both Rand and Cavell have discussed as the fear that drives skepticism. ${ }^{23}$ It is also, as I will endeavor to prove in this section, the fear that drives Derrida's practice of deconstruction. 
The "origin" of deconstruction can be traced back to Derrida's early engagements with the phenomenology of Edmund Husserl. Indeed, it is not overstating the case to equate the Derridean practice of deconstruction with the Husserlian practice of conducting "sense-investigations." In his introduction to his translation of Husserl's essay "The Origin of Geometry," Derrida identifies as the "main find" of his translation the presence of a "spiraling movement" in Husserlian sense-investigations which he argues points the way towards the "new form of radicality" he would eventually call deconstruction:

Concerning the intentional history of a particular eidetic science, a sense-investigation of its conditions of possibility will reveal to us exemplarily the conditions and sense of the historicity of science in general, then of universal historicity ... This would demonstrate, if it were still necessary, at what point the juridical order of implications is not so linear and how difficult it is to recognize the starting point (Derrida [1962] 1989: 33-34). ${ }^{24}$

Deconstruction, then, emerges from the fecundity indicated by Husserl of inquiring into the "conditions of possibility" for a particular discourse, "continually calling us back to the unnoticed presuppositions of ever recurring problems" (Derrida [1962] 1989: 52). ${ }^{25}$ Added to which, deconstruction is more than merely an available option for philosophers; it is, according to Derrida, a philosophical necessity insofar as "every critical enterprise" allegedly suffers from a "natural naiveté of its language" and thus requires "rigorous philological or "etymological"” investigation (Derrida [1962] 1989: 69-70). ${ }^{26}$ In Husserl's case, his “naiveté" is discernible in his "dogmatic" commitment to what Derrida famously termed the metaphysics of presence, a 
philosophical orientation according to which the "privilege" of presence was not only never put into question by Husserl (nor by any other like-minded philosophers going all the way back to Aristotle) - "it could not have been" (Derrida [1968a] 1982: 34, my emphasis). ${ }^{27}$

Derrida's entire line of argument here corroborates the presence in deconstruction of a fantasy of necessary inexpressiveness. At practically every turn, whether in his rare acts of introspection or his more frequent acts of extrospection, Derrida adamantly affirms to his readers (and thereby reaffirms to himself) that self-consciousness is an illusion, intentionality belongs only to that which is not human, and concepts such as responsibility and culpability are utterly superfluous in the realm of human existence. How strange it is, then, for poststructuralists to speak of "the ethics of deconstruction" (Critchley [1992] 2014) and proclaim that deconstruction "always has ethical and political stakes and consequences" (Bowman 2013: 19). If (a) there is no such thing as self-consciousness insofar as consciousness is inaccessible to the (non)self that is the human subject, and if (b) the consciousness of other human subjects is unknowable insofar as the necessary inexpressiveness inherent in language assures either silence or misunderstanding, then how is it possible for (a) and (b) to produce a (c) in which ethics is even conceivable? The idea of ethical responsibility often affirmed by poststructuralists is valid and noble (and consistent with Objectivism), but far from being deconstructionist, does it not fundamentally contradict Derrida's purpose with deconstruction?

But I am not there yet. Before considering the logical and moral consequences of Derrida's inability to resolve the contradictions at the heart of deconstruction, I want to consider in greater detail his critiques of Husserl, and in particular, his attempts to remove the self from 
consciousness. The ineffectuality of his critiques is attributable to his twin Kantian/Nietzschean bias and his consequent inability to apprehend the significance of the primacy of existence in Husserlian phenomenology. Interestingly, the axiom "existence exists" and the axiomatic concepts of existence, identity, and consciousness anchor phenomenology just as they anchor Objectivism (even if not in these precise Objectivist terms). Husserl also devoted a great deal of his energy, just as Rand did after him, to epistemological considerations; i.e., to considerations of the means by which human beings use their conceptual faculty to bring the objective, external world into the realm of the knowable. ${ }^{28}$ Unfortunately, due to his allegiance to Kant, Derrida invariably occludes in his critiques of Husserl the important fact that, for Husserl, both "inner" existence and "outer" existence are "immediately present" in consciousness (Derrida [1967] 1973: 43). ${ }^{29}$ As Vivian Sobchak affirms, according to Husserl, "the condition of being conscious of the world is being a consciousness in it" (Sobchak 1992: 59) ${ }^{30}$ Husserl, for his part, formulated his sense of the primacy of existence as follows:

When, through memories, starting from a perception, I am led back into my own past, this past is precisely my own, the past of this same subject who is present and living. And the past environing world [Umgebungswelt] which is now remembered belongs to the same world as the world in which I now live ... To introduce the matter of intersubjectivity, what we have said also holds true if another person tells me about his past experiences, communicates his memories ... The remembered environing world of the other, about which he tells us, may certainly be another world than that in which we find ourselves at present, and likewise the environing world which I myself remember may be another world; I can have changed my place of residence, have come to another 
country, with other men and other customs, etc., or this same geographical neighborhood with its inhabitants may have so changed in the course of a human life that it has simply become another; but, despite all this, all these different remembered environing worlds are pieces of one and the same objective world. This world is, in the most comprehensive sense, as the life-world for a human community capable of mutual understanding, our Earth (Husserl [1948] 1973: 162-163).

Objectivity is clearly an important concept for Husserl. As Derrida puts it in his introduction to “The Origin of Geometry," Husserl "repeatedly and obstinately" returns to the question of objectivity (Derrida [1962] 1989: 63). Despite his ability to register the importance of objectivity in Husserlian phenomenology, Derrida's reliance on the intrinsic/subjective dichotomy leads to a grotesque distortion of the concept. In one of his earliest engagements with Husserlian phenomenology, Derrida characterizes the phenomenologist in search of objectivity as "the "true positivist' who returns to the things themselves and who is self-effacing before the originality and primordiality of meanings" (Derrida [1959] 2001: 194). The point to be made in response to this nonsensical characterization is that the notion of effacing oneself is phenomenologically unthinkable inasmuch as it contradicts, in favor of the mystical "logic" that underpins intrinsicism, what Husserl calls the "necessary regress to the ego" in all sense-investigations (Husserl [1931] 1960: 6).

Now, to be fair to Derrida, his ill-advised recourse to the intrinsic/subjective dichotomy may have seemed the only option available to him given Husserl's own occasional confusion as to the means by which objectivity is epistemologically assured. For example, in his Formal and 
Transcendental Logic, Husserl asserts the following pertaining to his method of senseinvestigation:

We must place ourselves above this whole life and all this cultural tradition and, by radical sense-investigations, seek for ourselves singly and in common the ultimate possibilities and necessities, on the basis of which we can take our position toward actualities in judging, valuing, and acting. True, in that manner we gain nothing but universalities for which we can give an ultimate accounting ... whereas life, after all, consists in decisions of the "moment," which never has time to establish anything with scientific rationality (Husserl [1929] 1969: 5-6).

Even though Husserl sought to move beyond the errors committed by Descartes in his quest for "scientific rationality," he is here committing a number of the very same errors. ${ }^{31}$ The first and most serious error is discernible in the nonsensical impulse to place oneself "above" life. This impulse is eminently Cartesian; it betrays a mystical desire for knowledge to be revealed rather than produced. Rand points out that this mystical desire rests on "the unchallenged premise that any knowledge acquired by a process of consciousness is necessarily subjective and cannot correspond to the facts of reality, since it is "processed knowledge" - this despite the fact that "processed knowledge" is a pleonasm, for "all knowledge is processed knowledge - whether on the sensory, perceptual, or conceptual level. An 'unprocessed' knowledge would be a knowledge acquired without means of cognition" (Rand [1966-1967]: 1990: 81). 
In addition to this Cartesian error, Husserl also reifies a split between "theoretical" knowledge and "practical" knowledge. For Husserl, theoretical knowledge is rational, measured, and objective; it yields "universalities." Practical knowledge, on the other hand, is... what? Irrational? Unmeasured? Subjective? Husserl's incoherence in speaking of "decisions of the 'moment"' as somehow unreachable by rationality - thereby implying that rationality and practicality are mutually exclusive - is a holdover from the "contemptible breed" of mystics described by Rand as follows:

[They] profess a devotion to some sort of "pure knowledge" - the purity consisting of their claim that such knowledge has no practical purpose ... [and they] reserve their logic for inanimate matter [since they] believe that the subject of dealing with men requires and deserves no rationality ... [But] since there is no such thing as "non-practical knowledge" or any sort of "disinterested" action, since they scorn the use of their science for the purpose and profit of life, they deliver their science to the service of death (Rand 1957: 1066).

Considering Husserl's confusion vis-à-vis the intrinsic/subjective dichotomy, Derrida is right to apply pressure to the contradictions that undermine Husserlian objectivity. Derrida formulates Husserl's quest for objectivity as the attempt to "give rise" to an object that satisfies the criteria of 'omnitemporal validity, universal normativity, intelligibility for 'everyone,' uprootedness out of all 'here and now' factuality, and so forth," and this quest, as Derrida understands it, hinges on the answer provided to the question of how consciousness can "go out of itself in order to encounter or constitute the object" (Derrida [1962] 1989: 63). While Derrida is right to maintain 
Husserl's Cartesian confusion vis-à-vis consciousness going "out of itself," he inadvertently introduces even more confusion with two additional philosophical errors. The first error is Kantian in nature and is discernible in his equivocation between encountering an object and constituting an object, the two of which indicate precisely the difference between objectivity and subjectivity. The second error, meanwhile, is Cartesian in nature, and it is discernible in the following crucial part of Derrida's critique:

No doubt geometrical truth is beyond every particular and factual linguistic hold as such, one for which every subject speaking a determined language and belonging to a determined cultural community is in fact responsible. But the objectivity of this truth could not be constituted without the pure possibility of an inquiry into a pure language in general. Without this pure and essential possibility, the geometrical formation would remain ineffable and solitary. Then it would be absolutely bound to the psychological life of a factual individual, to that of a factual community, indeed to a particular moment of that life. It would become neither omnitemporal nor intelligible for all. It would not be what it is. Whether geometry can be spoken about is not, then, the extrinsic and accidental possibility of a fall into the body of speech or of a slip into a historical movement. Speech is no longer simply the expression of what, without it, would already be an object: caught again in its primordial purity, speech constitutes the object and is a concrete juridical condition of truth. The paradox is that, without the apparent fall back into language and thereby into history, a fall which would alienate the ideal purity of sense, sense would remain an empirical formation imprisoned as fact in a psychological subjectivity - in the inventor's head (Derrida [1962] 1989: 76-77). 
Beyond his Kantian confusion and the persistence of the intrinsic/subjective dichotomy, evident in this passage is an additional Cartesian confusion vis-à-vis Derrida's bizarre conception of language as an all-powerful causal agent that makes meaning and "always-already" thwarts human autonomy after the fashion of Descartes' evil demon. There is the presumption in Derrida's conception of language that, as Noël Carroll puts it, if human thought and action have "structural conditions," then these conditions are constraints, they are inimical to human autonomy. But Carroll observes how strange it is to think of these conditions of possibility as conditions of impossibility, for without these conditions, "nothing could be said, which would in fact be a real blow to the possibility of human autonomy" (Carroll 1988b: 78-79). More radical than Barthes' conception of the "pure" functionality of language, Derrida seems to hold that language is not just autonomous and omnipotent but malevolent to boot. The problem, then, is Derrida's conception of freedom, which, as Carroll argues, is "too extravagant":

This argument seems to presuppose that no speaking subject is free unless it creates the language it speaks. But this is absurd. If I have a hammer and I can use it to build a house, or a hobby horse, or simply use it to pound the ground, then it seems to me that I am free in what I hammer. And if I hammered someone who annoyed me - while certifiably sane - I would be responsible for my act since it was free. But [Derrida's] argument, by logical analogy, would have it that I am not free because I did not invent hammers. This idea of freedom, however, is unacceptably exorbitant, and any argument that uses it as a standard of what freedom is is unsound (Carroll 1988b: 78). 
If Derrida simply held the mistaken belief that language is not a "tool" that we "use" to "communicate" but an all-powerful force that uses us, then dissolving such a silly philosophical worry would be simple enough. The difficulty in dissolving Derrida's philosophical worry is due to his motivation in clinging to such a silly belief - which, as I mentioned at the start of this section, is his fear of the responsibility and accountability that comes with being human. ${ }^{32}$ Responsibility, to Derrida, means "shouldering a word one hears spoken, as well as taking on oneself the transfer of sense, in order to look after its advance" (Derrida [1962] 1989: 143). This responsibility is what Derrida has in mind when he confesses that "speaking frightens me" (Derrida [1964] 2001: 9); it is what motivates him to mobilize a nonsensical conception of language that, in his fantasy, "restricts meaning - and our responsibility for it" (Derrida [1964] 2001: 9, my emphasis). And Derrida's "solution," in the form of his quasi-Cartesian conception of language, is meant to ensure that "no intention can ever be fully conscious, or actually present to itself” (Derrida [1977] 1988: 73), which would mean, fulfilling Derrida's fantasy of necessary inexpressiveness, that language "leaves us no choice but to mean (to say) something that is (already, always, also) other than what we mean (to say), to say something other than what we say and would have wanted to say" (Derrida [1977] 1988: 62).

This fantasy of necessary inexpressiveness would, I admit, be a neat solution to the problems of consciousness and the issue of responsibility, and for many scholars who have followed in Derrida's wake, it has proven to be a satisfactory solution. Paul de Man, for instance, rejects on Derridean grounds the postulation of a "happy relationship" between consciousness and the external world since "the very fact that the relationship has to be established within the medium of language indicates that it does not exist in actuality" (de Man [1960] 1984: 8). John Mowitt, 
meanwhile, rejects in the realm of art the concept of value since it presupposes not only that there are objective attributes identifiable in artworks, but even more affrontingly, that artworks have, "presumably by virtue of their 'natures,' clear and distinct insides" immune to the “tenacious heterogeneity" of textual discursivity (Mowitt 1992: 215). And Paul Bowman rejects the concept of objective meaning since the invocation of objectivity "is enabled by something like a second 'structure,' one that is never fully knowable" (Bowman 2007: 64). Yet, despite the neatness of this solution, it is ultimately untenable. To prove this, it will be instructive to consider in detail the ubiquitous contradictions that prevent Derrida from ever actually indulging in his fantasy of necessary inexpressiveness. And, intriguingly enough, these contradictions are the clearest and most persistent in Derrida's attempts to move from his general philosophy of deconstruction to a deconstructive aesthetics.

After completing a dissertation on Husserlian phenomenology in 1954, Derrida set out, in 1957, to write a thesis on "the ideality of the literary object." 33 That thesis was never written, but as J. Hillis Miller convincingly argues, the ideas that motivated Derrida in his consideration of such a project underwrite his deconstructive aesthetics; they are everywhere, "from one end to the other of his work" (Miller 2001: 58). One of the earliest places where they emerge is in his 1964 essay "Force and Signification.” In this essay, Derrida explores such issues in the philosophy of art as artistic inspiration and creation, the ontology of literature, the vicissitudes of interpretation, and problems of evaluation, and he does so on the basis, primarily, of a critique of the literary criticism of Jean Rousset. According to Derrida, Rousset exemplifies in the philosophy of art the tendency to uncritically and dogmatically adhere to the metaphysics of presence and idealize the artistic object. Indicating the centrality of his critiques of Husserl to his deconstructive aesthetics, 
Derrida has in mind when speaking of the idealization of the artistic object the Husserlian idealization of mathematics. In his introduction to "The Origin of Geometry," Derrida identifies "the mathematical object" as "the privileged example and most permanent thread guiding Husserl's reflection." The privilege and permanence of the mathematical object in Husserlian phenomenology is, according to Derrida, attributable to its ideality, to its being "thoroughly transparent and exhausted by its phenomenality"; as an "absolutely objective" object, it is, at its most ideal, "totally rid of empirical subjectivity" (Derrida [1962] 1989: 27).

It is this form of Husserlian ideality that Derrida detects in Rousset's "ultrastructuralism," which he argues has the dangerous effect of cutting off from criticism the necessary "attentiveness to the internal historicity of the work itself," including its relationship to a "subjective origin" (Derrida [1964] 2001: 15). By deploying the concept of "origin," Derrida appears to be contradicting his stated aim in his introduction to "The Origin of Geometry" to dispense with what he refers to as the "mythology of the absolute beginning" (Derrida [1962] 1989: 69). To avoid erroneous claims of contradiction, it must be clarified that Derrida is here invoking a modified conception of "origin" based on the following explanation provided by Husserl as to the trajectory of his sense-investigation into the origins of geometry:

The question of the origin of geometry (under which title here, for the sake of brevity, we include all disciplines that deal with shapes existing mathematically in pure space-time) shall not be considered here as the philological-historical question, i.e., as the search for the first geometers who actually uttered pure geometrical propositions, proofs, theories, or for the particular propositions they discovered, or the like. Rather than this, our interest 
shall be the inquiry back into the most original sense in which geometry once arose, was present as the tradition of millennia, is still present for us, and is still being worked on in a lively forward development; we inquire into that sense in which it appeared in history for the first time - in which it had to appear, even though we know nothing of the first creators and are not even asking after them (Husserl [1939] 1970: 354, my emphasis).

Following Husserl, Derrida further clarifies his conception of "origin" in the following manner:

It is not at all a question of determining what in fact were the first acts, the first experiences, the first geometers who were in fact responsible for the advent of geometry. Such a determination, even if possible, would flatter our historical curiosity ... [and] a certain 'romanticism' ... but even if, at its limit, this determination would embrace all the historical facts that have constituted the empirical milieu for truth's founding, it would still leave us blind about the very sense of such a founding: a sense that is necessary and compared to which these facts have at best only an exemplary signification (Derrida [1962] 1989: 37-38).

If this explains what Derrida means by "origin," it remains to be explained what he means by subjective origin. If the "subjective origin" of geometry is not traceable to the "primally instituting geometer" (Derrida [1962] 1989: 100), then the "subjective origin" of an artwork should not be traceable to its "author." 34 Indeed, according to the terms of Derrida's critique of Rousset's "ultrastructuralism," the very notion of a "center" or "ground" for the meaning of an artwork is anathema to his deconstructive aesthetics. This may be corroborated by considering 
Derrida's critique of Rousset in light of his subsequent critique of the structural anthropology of Claude Lévi-Strauss, in which Derrida focuses on the problematic concept of the "center" that is presupposed in the concept of structure:

The function of [the] center [is] not only to orient, balance, and organize the structure one cannot in fact conceive of an unorganized structure - but above all to make sure that the organizing principle of the structure would limit what we might call the play of the structure ... The concept of centered structure is in fact the concept of a play based on a fundamental ground, a play constituted on the basis of a fundamental immobility and a reassuring certitude, which itself is beyond the reach of play. And on the basis of this certitude, anxiety can be mastered (Derrida [1966] 2001: 352). ${ }^{35}$

Against the (metaphysical) concept of "structure" and its presupposition of a (Lévi-Straussian) "center" or (Husserlian) "ground," the result of which is, in the "geometrism" of Rousset's criticism, an "ideal" artistic object, Derrida argues for unstructured, ungrounded, decentered "play." Yet, at the beginning of his critique of Rousset, Derrida acknowledges that meaning in art "is the author's responsibility before being the critic's" (Derrida [1964] 2001: 4). This ambivalence regarding the artwork - on the one hand, understood as possessing an "internal historicity" and a "subjective origin," and, on the other hand, understood as "a world of signs without fault, without truth, and without origin" (Derrida [1966] 2001: 369) - highlights the fundamental contradiction of Derrida's deconstructive aesthetics, one that he never successfully resolves. 
In "Force and Signification," Derrida acknowledges the logical priority of authorship in criticism. However, in a reading of Franz Kafka's The Trial (1925), he contradicts this sensible position and derides the "law" of authorship and the equally silly belief in objective, discoverable meaning. ${ }^{36}$ Reversing course again, in his critique of Lacan's reading of Edgar Allan Poe's “The Purloined Letter" (1844), Derrida takes Lacan to task for failing to consider Poe's authorship over the course of his analysis and, for his part, engages in detailed, authorbased criticism. ${ }^{37}$ Finally, within the space of a single interview, Derrida discusses the authorship of James Joyce as an "absolutely singular event," an absolutely singular "autobiographical inscription" in which "historical, theoretical, linguistic, [and] philosophical culture" are condensed (Derrida [1989] 1992: 43), yet at the same time maintains that there is an irreducible "literary intentionality" that "suspend[s] 'thetic' and naive belief in meaning" (Derrida [1989] 1992: 45).

Throughout his entire career, Derrida remained tragically torn between two warring conceptions of life and art, one in which "the category of intention will not disappear" (Derrida [1972] 1988: 18) and another where intention disappears in the act of "Logos retaking possession of itself" (Derrida [1962] 1989: 146). The significance of the concept of intention (and the concept of meaning necessarily implied) is made explicit in Derrida's defense, in response to the criticisms of John Searle, of his concept of "iterability" 38 :

If the law of iterability, with all its associated laws, exceeds the intentional structure that it renders possible and whose teleo-archaeology it limits ... then the question of the specificity of intentionality in this field without limit remains open: what is 
intentionality? What does "intention" properly mean as the particular or original work (mise en oeuvre) of iterability? I admit that this enigma grows increasingly obscure for me. It communicates with the greatest questions of being, of meaning and of the phenomenon, of consciousness, of the relation to the object in general, of transcendence and of appearing as such, etc ... [which] only cause[s] my uncertainty to increase, as well as my distrust of this word or of this figure, I hardly dare to say "concept" (Derrida [1988] 1988: 130).

This passage indicates the logical and moral consequences, in life and art, of the confusions and contradictions regarding objectivity, consciousness, and intention that I have been discussing in Derrida's philosophical practice. The notion that iterability "renders possible" and "limits" the concept of intention follows from Derrida's quasi-Cartesian conception of language as the condition of possibility and impossibility of human autonomy. Furthermore, Derrida's "glass half empty" approach to iterability as the condition of impossibility of human autonomy confirms for Derrida that intention can never be "fully conscious" or "actually present to itself." The fact that Derrida was never able to actually indulge in this fantasy of necessary inexpressiveness is due to his recognition (acknowledged in moments of courage, denied in moments of fear) of the following unfortunate consequences:

1) If intention can never be "fully conscious," then ethics, responsibility, authorship - in short, all concepts that are predicated on human beings as conscious, volitional entities - are null and void. $^{39}$ 
2) If ethics and responsibility are not valid concepts, then deconstruction loses its sense and purpose. $^{40}$

3) If authorship is not a valid concept, then the concept of meaning in art loses its sense and purpose. $^{41}$

Even though Derrida was never able to successfully resolve these contradictions, he did acknowledge near the end of his life, with disarming sincerity, the problematic ubiquity in his work of contradictions. In his last interview, conducted mere weeks before his death, Derrida stated the following:

It is true, I am at war with myself, and you have no idea to what extent, more than you can guess, and I say things that contradict each other, that are, let's say, in real tension with each other, that compose me, that make me live, and that will make me die. This war, I see it sometimes as a terrifying and painful war, but at the same time I know that it is life ... [Deconstruction thus] proceeds with me from an unconditional affirmation of life ... [it] is not death-oriented, just the opposite, it is the affirmation of someone living who prefers living, and therefore survival, to death (Derrida 2004: 12).

In light of this admirably honest and heartfelt confession from Derrida, which depicts nothing if not a man tortured by his own fears and inadequacies yet unwilling to acquiesce to nihilism, is Jonathan Culler's characterization of deconstruction not profoundly - even shockingly insulting? 
[Deconstruction] cannot be brought together in a coherent synthesis. For this reason, it may not seem [valid] to many, who would argue that logic forbids [contradiction] ... The objection to this double procedure [invokes] ... physical and empirical inappropriateness: deconstruction's procedure is called "sawing off the branch on which one is sitting." This may be, in fact, an apt description of the activity, for though it is unusual and somewhat risky, it is manifestly something one can attempt. One can and may continue to sit on a branch while sawing it ... The question then becomes whether one will succeed in sawing it clear through, and where and how one might land ... If "sawing off the branch on which one is sitting" seems foolhardy to men of common sense, it is not so for Nietzsche, Freud, Heidegger, and Derrida; for they suspect that if they fall there is no "ground" to hit (Culler 1982: 149).

If, as attested to by Ludwig Wittgenstein, philosophical errors "can be fitted into what [one] knows aright" (Wittgenstein [1951] 1969: 11e), then the possibility of a redemptive critique of Derrida and deconstruction gains considerable purchase. It is a testament to the degeneracy of poststructuralism, however, that the first step in such a rescue effort would have to be to rescue Derrida and deconstruction from poststructuralism. After all, given Derrida's own disposition, any poststructuralist with even a passing familiarity with Derrida and his work should find horrifying the magnitude of abasement in Culler's repulsive caricature of deconstruction. First of all, the fact that Derrida was unable to bring deconstruction into a "coherent synthesis" and was unable to resolve its fundamental contradictions is not, as Culler would have it, an indication of its success. This backwards "logic" might fly in reference to Barthes and his desire to "discard" 
the "old specter" of "logical contradiction" in pursuit of the primordial jouissance of the infinitely polysemous text, but it is anathema to Derrida's lifelong commitment to logic and morality. ${ }^{42}$ Added to which, the characterization of Derrida as gleefully sawing off the branch on which he was sitting in a spirit of philosophical anarchy reduces the pathos of his sincere quest for knowledge of the world and his place in it to something out of Looney Tunes. ${ }^{43}$

The fact that, far from precipitating a swarm of scholars rushing to his defense, Culler's explication of deconstruction was accepted by poststructuralists as the authoritative account of Derrida and his philosophical practice indicates the staggering amount of work facing anyone who wishes to undertake a redemptive critique of deconstruction. First and foremost, it will be necessary to dissolve the philosophical worries that led Derrida into philosophical error and that are responsible for the contradictions at the heart of deconstruction. To his credit, the path for dissolving these philosophical worries, although never followed, was charted by Derrida himself in his moments of courage. As he once acknowledged, in a decidedly Objectivist spirit, it is essential that one lives according to a logic of "all or nothing":

Every concept that lays claim to any rigor whatsoever implies the alternative of "all or nothing" ... Even the concept of [for example] relativity is, qua concept, determined according to the logic of all or nothing, of yes or no ... It is impossible or illegitimate to form a philosophical concept outside this logic ... [and] whenever one feels obliged to stop doing this (as happens to me when I speak of différance, of mark, of supplement, of iterability, and of all they entail), it is better to make explicit in the most conceptual, 
rigorous, formalizing, and pedagogical manner possible the reasons one has for doing so (Derrida [1988] 1988: 116-117).

Strangely enough, the logic of all or nothing to which Derrida aspired with deconstruction is precisely the logic of Objectivism:

Man cannot survive except by gaining knowledge, and reason is his only means to gain it. Reason is the faculty that perceives, identifies, and integrates the material provided by his senses. The task of his senses is to give to him the evidence of existence, but the task of identifying it belongs to his reason ... His means [of identification] is logic, and logic ... is the art of non-contradictory identification ... No concept man forms is valid unless he integrates it without contradiction into the total sum of his knowledge. To arrive at a contradiction is to confess an error in one's thinking; to maintain a contradiction is to abdicate one's mind and to evict oneself from the realm of reality (Rand 1957: 10161017).

Cavell once characterized skepticism as the history of one's turnings, "in distraction or denial," from reality (Cavell [1971] 1979: 114). Analogously, deconstruction serves as the history of Derrida's turnings from reality. For giving in to fear and continually turning from reality, Derrida paid the price that all skeptics are forced to pay, the price of, in Cavell's terminology, "living one's skepticism": 
In saying that we live our skepticism, I mean to register [an] ignorance about our everyday position ... Not that we positively know that we are never, or not ordinarily, in best cases for knowing ... but that we are rather disappointed in our occasions for knowing, as though we have, or have lost, some picture of what knowing ... would really come to - a harmony, a concord, a union, a transparence, a governance, a power - against which our actual successes at knowing, and being known, are poor things. To say that there is a skepticism which is produced [not just] by a doubt about whether we can know [but also] by a disappointment over knowledge itself, and to say that this skepticism is lived ... is to say that this disappointment has a history (Cavell 1979: 440).

It is on the basis of this picture of the skeptic as doubtful, fearful, and perpetually disappointed in his attempts to alleviate his doubts and fears that D.N. Rodowick makes the case that what philosophy requires is not further conceptual fine-tuning - which was Derrida's proposed solution with his array of idiosyncratic concepts - but rather a "diagnosis or etiology" of the reasons one is compelled to turn from reality (Rodowick 2015: 201). If there exists anything in the philosophy of art that proves Rodowick's contention, it is the philosophical practice of deconstruction as it was developed and practiced by Jacques Derrida.

\section{Conclusion}

In this essay, I have framed my elephantine endeavor as a Dante-esque descent into the poststructuralist Inferno. However, by way of a conclusion, I think it is important to stress that, from a certain Objectivist perspective (similar to the Objectivist distinction between evil and 
error stressed in the previous section), the fact that contemporary art criticism has accepted the aesthetic principles of poststructuralism is not proof of scholars" "essential evil"; rather, it is "a great and tragic proof of [their] essential morality" (Rand [1943] 1995: 87-88), of their willingness to always consider alternative methodologies and constantly "check their premises." This determination on the part of scholars to be wary of error, ignorance, prejudice, etc., is not a vice. In fact, it is a virtue. However, it is important for scholars to be vigilant regarding what Rand called the "dangerous little catch-phrase" of "keeping an open mind," for as she warned:

This is a very ambiguous term - as demonstrated by a man who once accused a famous politician of having "a wide open mind." That term is an anti-concept: it is usually taken to mean an objective, unbiased approach to ideas, but it is used as a call for perpetual skepticism, for holding no firm convictions and granting plausibility to anything ... What objectivity and the study of philosophy require is not an "open mind" but an active mind ... An active mind does not grant equal status to truth and falsehood, it does not remain floating forever in a stagnant vacuum of neutrality and uncertainty; by assuming the responsibility of judgment, it reaches firm convictions and holds to them ... If you keep an active mind, you will discover (assuming that you started with common sense rationality) that every challenge you examine will strengthen your convictions, that the conscious, reasoned rejection of false theories will help you to clarify and amplify the true ones, that your ideological enemies will make you invulnerable by providing countless demonstrations of their own impotence. No, you will not have to keep your mind eternally open to the task of examining every new variant of the same old falsehoods. You will discover that they are variants or attacks on certain philosophical 
essentials - and that the entire, gigantic battle of philosophy (and of human history) revolves around the upholding or the destruction of these essentials (Rand [1974b] 1982: 21-22).

Proceeding from the notion of the sanction of the victim, it is one of the principles of Objectivism that "there comes a point in the defeat of any man of virtue when his own consent is needed for evil to win" (Rand 1957: 1048). If, in Randian terms, the gigantic battle of the philosophy of art revolves around upholding or destroying the concept of authorship, then it is not possible for the concept of authorship to be destroyed unless those committed to upholding it sanction its destruction. Arguments against authorship are, in and of themselves, harmless. Only when they are given the sanction of reason do they become dangerous. As Rand made clear, a basic premise is "an absolute that permits no cooperation with its antithesis and tolerates no tolerance" (Rand 1957: 741-742). As it relates to art criticism, any scholar who accepts the denial of the basic premise of authorship is guilty of "granting the sanction of reason to formal dementia" and "it is they who achieve the destruction of the mind" (Rand 1957: 741).

It is undeniable that the morass of contemporary art criticism makes it difficult to envision a change in course. But it is important to acknowledge two facts: First, that change is possible; second, that silence $i$ s sanction. To reverse the tide of irrationality in contemporary art criticism and to establish a solid foundation on which to construct an Objectivist aesthetics, scholars must build up their endurance, exercise their patience, and refute the unreadable. Only then will the roads be clear and will we be able to go back to the world of art. 


\section{NOTES}

For providing generous encouragement and insightful criticism throughout the writing process, I would like to thank Paul Bowman and Evelina Kazakevičiūtè.

${ }^{1}$ For examples of his propensity for combat metaphors, see Aristotle ([350 BC] 1995: 566, 1654, 4680, 4697).

${ }^{2}$ Beyond the work of Leonard Peikoff (1991) and Allan Gotthelf (2000), both of whom seemed to discuss aesthetics solely for the sake of comprehensiveness, the only substantial writing on Objectivist aesthetics has been the work of Louis Torres and Michelle Marder Kamhi (2000). This lacuna has only recently been addressed, first in the "Aesthetics Symposium" in Volume 2 Number 2 (2001) of this journal, which essentially served as a series of responses to Torres and Kamhi's work, and subsequently in the promising work of Kirsti Minsaas (2000, 2004, 2005, 2007), Stephen Cox $(2000,2004)$, and Roger E. Bissell $(2002,2004)$. There is perhaps a correlation between the sparseness of scholarship on Rand's aesthetic writings and the sparseness of Rand's writings themselves. Cox characterizes Rand's philosophical musings on aesthetics as less than a true aesthetic system and more on the level of gathering the conceptual building materials necessary for sustained aesthetic inquiry; in The Art of Fiction ([1958] 2000), a collection of lectures transcribed, collated, and published posthumously, and The Romantic Manifesto ([1969] 1975), a collection of essays edited together and published by Rand herself, Rand is concerned with inventorying the conceptual material she considered vital in aesthetic inquiry, some of which she "organized and began to shape" but most of which she "simply checked off on her inventory list" (Cox 2004: 67). In a similar vein, Peikoff views Rand's 
aesthetic inventory as providing "merely a lead to some broad aesthetic principles [that] would have to be applied specifically to the major arts" (Peikoff 1991: 447). This essay will hopefully encourage more scholars to apply Objectivist principles to the major arts and to defend the major arts from the myriad irrational/immoral principles that have been destroying art criticism for decades.

${ }^{3}$ At one point in a discussion of metaphysics, Rand explained her "razor" as follows: "In an ideal Atlantis, every philosopher would be asked to name his axioms before being permitted to utter a proposition" (Rand [1966-1967] 1990: 251).

${ }^{4}$ I should mention that, in what follows, I will be working exclusively from the most famous English translations of Barthes' and Derrida's texts. If scholars wish to impugn my arguments on the grounds that I am not engaging with the original French texts, then it is their burden to prove that the nonsense critiqued in this essay is limited only to the English translations.

${ }^{5}$ In literary theory, Barthes' essay disturbed the semblance of peace that had been achieved following the publication of Monroe C. Beardsley and W.K. Wimsatt Jr.'s controversial essay on “the intentional fallacy" (Beardsley and Wimsatt Jr. 1946). In a sense, Barthes' position represents a radicalization of what is known in literary theory as "New Criticism," which, to Barthes' mind, failed in its attempts to invalidate the concept of authorship and instead did "no more than consolidate it" (Barthes [1967] 1977: 143). Barthes' radicalism was embraced, with varying degrees of extremism, by countless literary theorists, notably those associated with the French publications Communications and Tel Quel and with what eventually came to be known as the "Yale School" of literary criticism. It inspired Jean-Louis Baudry to attempt to explode the temporal logic of writing and reading and reconceive them as "merely simultaneous moments in a single process of production" (Baudry quoted in Rodowick [1988] 1994: 28); it inspired 
Terence Hawkes to reject as "dishonest" all criticism "based on the supposition that the [artwork] exists in some objective, concrete way before the critical act" (Hawkes 1977: 155) and to imperiously affirm in place of such criticism a mode of reading that "tears away the veil" of authorship based on the supposition that the artwork "remains genuinely ours to make and to remake as we please" (Hawkes 1977: 73); and it inspired J. Hillis Miller to proclaim that authorial intention can never be "wholly explained, after the fact, by however exhaustive a retrospective repertory of [artworks], including the psychobiographies of the authors in question" and to encourage instead an emphasis on "the residue of the unexplained" (Miller 1998: 85). Film scholars, too, were swept up by the radical spirit of Barthes' essay, particularly those associated with the famous French film journal Cahiers du Cinéma in the late 1960s/early 1970s and with the influential British journal Screen in the 1970s and into the 1980s. It inspired criticfilmmaker Jacques Rivette to urge filmmakers and filmgoers alike to renounce "all the bourgeois aesthetic clichés: like the idea that there is an auteur of the film, expressing himself" (Rivette [1968] 1986: 319); it inspired Jean Narboni to champion a criticism that deprives films of "the author, the Creator, the 'temperament' through which Nature must be seen" (Narboni [1970] 1990: 151); and it inspired Stephen Heath to denounce the notion of an "englobing consciousness" capable of intending/being responsible for the particular "articulation of the film text" (Heath 1973b: 89). These are merely choice examples of nonsense meant to illuminate the logical consequences of embracing the aesthetic principles of poststructuralism.

${ }^{6}$ It is interesting to note that Austin's philosophical practice aligns perfectly with the philosophical method prescribed by Ludwig Wittgenstein: "Most of the [questions] to be found in philosophical works are not false but nonsensical. Consequently, we cannot give any answer to questions of this kind, but can only point out that they are nonsensical ... [Thus,] the correct 
method in philosophy would really be the following: to say nothing except what can be [sensibly] said ... and then, whenever someone else wanted to say something [nonsensical], to demonstrate to him that he had failed to give a [sensible] meaning to certain signs in his propositions. Although it would not be satisfying to the other person - he would not have the feeling that we were teaching him philosophy - this method would be the only strictly correct one" (Wittgenstein [1921] 2001: 22-23 [4.003], 89 [6.53]). More interesting still, both Austin's and Wittgenstein's positions on philosophical argumentation are also similar to the practice of what Rand referred to as philosophical detection (Rand [1974b] 1982). The unifying theme is the idea that it is possible to discover "the fundamental premises that underlie and shape men's statements on intellectual issues" (Peikoff [1981] 1993: 12).

${ }^{7}$ Even though Barthes is content to leave his distinction between deciphering and disentangling poetically vague, the implication, if not convincing, is at least clear: Since, without an author to "authorize" its meaning, a text can no longer be said to "have" (a) meaning, it is less like a "message" and more like, as Barthes claims, "the thread of a stocking," which can be "followed" or "run" - in a word, disentangled - but "beneath" which "there is nothing" to decipher (Barthes [1967] 1977: 147). That this formulation entails a significant reconceptualization of what art is and what an artwork does is an issue that, while beyond the scope of this essay, at least warrants mentioning.

${ }^{8}$ The two most relevant writings regarding Barthes' conception of a hedonistic aesthetics are “From Work to Text" (Barthes [1971] 1977) and The Pleasure of the Text ([1973] 1975). For a brief description of the Nietzschean "ideal" manifest in Barthes' hedonistic aesthetics, consider the following passage: "There exists a pleasure of the work ... but this pleasure, no matter how keen ... [remains] a pleasure of consumption; for if I can read [certain] authors, I also know that 
I cannot re-write them ... As for the Text, it is bound to jouissance, that is to a pleasure without separation" (Barthes [1971] 1977: 164). As for the stakes of pursuing this "pleasure without separation," Barthes is admirably clear with respect to how thoroughly it separates him from reality: "Imagine someone (a kind of Monsieur Teste in reverse) who abolishes within himself all barriers, all classes, all exclusions, not by syncretism but by simple discard of that old specter: logical contradiction; who mixes every language, even those said to be incompatible; who silently accepts every charge of illogicality, of incongruity ... Such a man would be the mockery of our society: court, school, asylum, polite conversation would cast him out: who endures contradiction without shame? Now this anti-hero exists: he is the reader of the text at the moment he takes his pleasure" (Barthes [1973] 1975: 3). In line with the Cavellian notion that one cannot just not know that which is known philosophically, I am reminded of a similar sentiment once expressed by Wittgenstein: "In certain circumstances a man cannot make a mistake ... [which means] we should not just not share his opinion: we should regard him as demented" (Wittgenstein [1951] 1969: 23e).

${ }^{9}$ The "logic" of Barthes' arguments here in "The Death of the Author" indicates a significant deviation from his earlier work in which authors were acknowledged as individuals possessing and capable of acting on conscious intentions. For example, in Writing Degree Zero, Barthes claims that the author "shows himself clearly as an individual" in his "choice of" and "responsibility for" a "mode of writing." Indeed, Barthes conceives writing as "the morality of form" and he acknowledges, in a curiously Objectivist gesture, that a morality of form presupposes volition on the part of the author (Barthes [1953] 2012: 14-16). I will elaborate on the moral consequences of Barthes' arguments in "The Death of the Author," which deny the eminently rational claims for authorship made in Writing Degree Zero, later in this section. 
${ }^{10}$ With reference to the Hegelian Cunning of Reason, Slavoj Žižek seeks to clarify that the correct reading "in no way involves a faith in a secret guiding hand" (Žižek 2012: 510). As for the insidiousness of language often attributed to Lacan (and endorsed, as I will discuss in the next section, by Derrida), Bruce Fink provides a diagrammatically clear explication when he alleges that "language 'lives' and 'breathes' independently of any human subject. Speaking beings, far from simply using language as a tool ... are the playthings of language, and are duped by language" (Fink 1995: 14). Incidentally, I say "attributed to" Lacan rather than "proposed by" or "promulgated by" Lacan because, contra Fink, Lacan argues that language is a tool for making meaning - or, to use Lacan's own word, an “instrument" (Lacan [1953] 2006: 227). The caveat is that, in Lacanian psychoanalysis, it is the unconscious that is responsible for using language to make meaning. That the psychoanalytic concept of the unconscious is no less mystical than capital-L Language is a fight for another day. The fact remains that, for Lacan, language and the unconscious are distinct and it is the latter that uses the former as a meaningmaking instrument. For more on Lacan's conception of language, see, among his many seminars and publications, Lacan ([1953, 1955, 1957, 1958] 2006, [1954-1955] 1991, [1972] 1998).

${ }^{11}$ Oddly enough, despite his allegiance to the semiological principles explicated by Ferdinand de Saussure, Barthes is here blatantly contradicting Saussure, who, for his part, maintained (sensibly) that "language is not an entity" (Saussure [1916] 2011: 5). In an effort not to misrepresent Saussure, I should mention that he does go on to say that, even if formulations such as "language does this or that" or "life of language" contradict the facts of reality, one "must not go too far" and "require that only words that correspond to the facts" be permitted (Saussure [1916] 2011: 5). I would, indeed, go so far as to say - in line with the Wittgensteinian notion of philosophy being "a battle against the bewitchment of our intelligence by means of language" 
(Wittgenstein [1949] 1967: 47e) - that only words that correspond to the facts ought to be used, and if an example is necessary to prove the disastrous consequences of countenancing language that contradicts the facts of reality, I shudder to think that there exists a better example than "The Death of the Author."

${ }^{12}$ For an even more explicit reliance on authorial intention in Barthes' critical practice, see his classically author-based essay - which, strangely, was written three years after "The Death of the Author" and one year before "From Work to Text" and originally published in the famous French film journal Cahiers du Cinéma at the height of its militant Marxism - entitled "The Third Meaning: Research Notes on Some Eisenstein Stills" (Barthes [1970] 1977), in which Barthes claims that the films of Sergei Eisenstein bear his "imperishable signature" (Barthes [1970] 1977: 64).

${ }^{13}$ Once again, Barthes is significantly deviating from his earlier work. In Writing Degree Zero, Barthes chronicles "the multiplication of modes of writing" (Barthes [1953] 2012: 84) and assesses Mallarmé's artistic practice as merely one mode among many. In "The Death of the Author," however, Mallarmé's artistic practice is no longer merely one possible mode; it has now become the only acceptable mode. I will explain the reason for this shift presently.

${ }^{14}$ The conjunction of authorship and capitalism here reminds me of the famous remark made by Walter Benjamin that “capitalism will not die a natural death" (Benjamin [1927-1940] 1999: 667).

${ }^{15}$ This is confirmed by Barthes, who proudly proclaims that the "poignant self-destruction" of such nonsensical artistic endeavors "has the very structure of suicide" (Barthes [1953] 2012: 75). ${ }^{16}$ Discerning readers might wonder where Barthes and other proponents of the notions of the death/nonexistence of the author and the "pure functionality" of Language stand regarding their 
own writings (or if they even consider writings that bear their names "their" "own"). Robin Wood, for example, in a consideration of Stephen Heath's famous analysis of the Orson Welles film, Touch of Evil (1958), highlighted Heath's condescension regarding film scholars who view Welles" work as a "breathtaking achievement" of "extraordinary" "genius," yet observed how "Heath's entire article, by the way, has the air of presenting itself as a 'breathtaking achievement,"' a curious glitch in the poststructural matrix that he wryly attempted to explain by postulating that "perhaps Heath did not write but was written at that point, i.e., he lapsed into a kind of lazy automatic doodling" (Wood [1988] 2002: 17; cf. Heath 1975a, 1975b). Barthes himself, meanwhile, in a written forward to an interview for the journal Tel Quel, used the strategy of distinguishing "himself" (without offering a positive conception of who/what "he" "was") from both the autobiographical "I," which "must be taken as if the person speaking were the same (in the same place) as the person who had lived," as well as from "the person whose birth date is the same as mine, 12 November 1915," who/which is "entirely imaginary" (Barthes [1971] 1998: 249). However, as once again pointed out by Wood, this strategy of mystification "raises more problems than it solves," for "one has to posit such an intimate connection between the ["real"/"imaginary" entities] that we are really back where we started" (Wood [1988] 2002: 15-16). The most honest way to actively function within this nonsensical realm is exemplified by Paul Bowman, who, at the end of his introduction to Mythologies of Martial Arts, a book written in an explicitly Barthesian spirit, avers that "every book is incomplete" and that, per Barthes, works are "abandoned" by their self-negating, suicidal authors (Bowman 2017: xxiii). While this position may be more honest and scrupulous than those of Heath or Barthes himself, it nevertheless has its own problems on the order of the altruist conception of authorship and the 
problematic necessity of such self-sacrifice which it entails. I will elaborate on this problem presently.

${ }^{17}$ The fact that it is unclear whether Barthes believes art always was and always will be constitutively destructive to authors or whether he believes art is now and should forever be approached by authors as a self-destructive practice is a significant and telling equivocation. It is on this point that the utility for Barthes of the criticism playbook of Ellsworth Toohey, the villain in Rand's novel The Fountainhead and an exemplar of the altruist (corruption of) morality, becomes clear. As Toohey explains at one point in a famous speech: “Empty man's soul - and the space is yours to fill" (Rand [1943] 1994: 666).

${ }^{18}$ Cavell provides a succinct refutation of this ubiquitous package deal: "What is discredited [in "The Death of the Author"] is [a straw man], a picture of human creation as a literalized anthropomorphism of God's creation - as if to create [an artwork] I were required to begin with the dust of the ground and magic breath" (Cavell [1984] 1988: 111).

${ }^{19}$ It warrants mentioning that even poststructuralists who claim to reject the "extreme" terms of Barthes' arguments against authorship still ultimately promulgate the exact terms of and conclusions reached in his arguments. Consider, as exemplary of this (foolish at best and disingenuous at worst) position, Samuel Weber's dealings with Barthes in his well-known Institution and Interpretation. In his Introduction, Weber acknowledges that "Barthes' obituary has proven premature" (Weber [1987] 2001: xv), yet this does not stop him from repeating exactly and on more than one occasion Barthes' arguments against authorship (presumably because he either feels Barthes' obituary was not premature or because he feels it is his responsibility to finish what Barthes started). In a critique of Wolfgang Iser's The Act of Reading (1978), Weber asks the metaphysical nonquestion “Who - or what - controls the text?" (Weber 
[1987] 2001: 184) and then tries to answer it via package dealing, arguing that "the author" is a "secular emanation" of the "Divine Creator" and to that extent "never speaks for itself" (Weber [1987] 2001: 196). This despite the facts that (a) authors very often speak for themselves and (b) the Author-God is a straw man.

${ }^{20}$ Gone in this passage from "The Death of the Author" is the subtlety of Barthes' prior conceptualizations of the activity of reading. Consider, as an example of Barthes' transient lucidity, the following postulation (in a section significantly titled "Objectivity") from Criticism and Truth: "Nobody has ever denied or will ever deny that the language of the text has a literal meaning ... What we need to know is whether or not one has the right to read in this literal language other meanings which do not contradict it" (Barthes [1966] 2007: 5-6). Leaving aside the irony in the fact that Barthes, in "The Death of the Author," is doing precisely what he, in Criticism and Truth, assured no one will ever do, Barthes' consideration in Criticism and Truth of the ethics of reading is as elegant and rational as it is nuanced and provocative. It is unfortunate that the more dramatic and polemical (and less rational and sensible) formulations of "The Death of the Author" have sedimented into critical dogma, thereby occluding the far more stringent efforts discernible in Barthes' earlier work.

${ }^{21}$ This reversal is even more explicit in "From Work to Text" in which Barthes decrees that "no vital 'respect' is due to the Text: it can be broken" (Barthes [1971] 1977: 161). Ironically, in a consideration of theories of textual analysis in relation to Freudian psychoanalysis, Weber notes that "to disfigure a text and to commit a murder" are "similar" acts (Weber [1987] 2001: 76) insofar as, in Freudian terms, "the difficulty lies not in the execution of the deed but in the doing away with the traces" (Freud [1937] 1939: 70). It would appear that Freud's perspicuous observation did not prevent Barthes (any more than it prevented Weber) from going ahead with 
his attempted murder, perhaps because he was confident he would be able to do away with the traces.

${ }^{22}$ That the romanticism implicit in my critique here becomes explicit must, in the interest of space, remain undeveloped. For a more elaborate treatment of romanticism between philosophy and art, see Rand ([1969] 1975). Additionally, my emphasis on the concept of acknowledgment is meant to indicate on this issue an affinity between Rand and Cavell. For the latter's many considerations of romanticism between philosophy and art (in which acknowledgment is a signal concept), see, in particular, Cavell ([1969] 2002, 1979, 1988).

${ }^{23}$ Against skeptics such as Descartes and Kant, Cavell argued, following Austin and Wittgenstein, that what he calls "the truth of skepticism" is that, inasmuch as "what skepticism questions or denies my knowledge of is the world of objects I inhabit, is the world" (Cavell 1979: 448), the desire of skeptics to know with certainty the existence of the world paradoxically gives ground to "a sense of powerlessness" in the face of "the precariousness and arbitrariness of existence, the utter contingency in the fact that things are as they are" (Cavell 1979: 236). On this picture, a more accurate name for skepticism presents itself: Fear. Through the act, motivated by fear, of sealing off from human knowledge the world in its awe-inspiring immediacy and intractability, skeptics create in its place $a$ world that they fancy as subject to their whims. The skeptic's experience of trying to prove that existence exists, moreover, is "one of trying to establish an absolutely firm connection with that world-object from that sealed position," a self-defeating task undertaken "as though, deprived of the ordinary forms of life in which that connection is, and is alone, secured, [the skeptic] is trying to establish it in his immediate consciousness, then and there" (Cavell 1979: 238). Rand, for her part, adds color to the picture painted by Cavell of the fear that drives skepticism when she notes that "every form 
of causeless self-doubt, every feeling of inferiority and secret unworthiness, is, in fact, man's hidden dread of his inability to deal with existence. But the greater his terror, the more fiercely he clings to the murderous doctrines that choke him ... He will fake, evade, blank out; he will cheat himself of reality, of existence, of happiness, of mind; and he will ultimately cheat himself of self-esteem by struggling to preserve its illusion rather than to risk discovering its lack ...... A [skeptic] is a man who surrendered his mind at its first encounter with the minds of others. Somewhere in the distant reaches of his childhood, when his own understanding of reality clashed with the assertions of others, with their arbitrary orders and contradictory demands, he gave in to so craven a fear of independence that he renounced his rational faculty ... [That is why,] when you listen to a [skeptic's] harangue on the impotence of the human mind and begin to doubt your consciousness, not his, when you permit your precariously semi-rational state to be shaken by any assertion and decide it is safer to trust his superior certainty and knowledge, the joke is on both of you: your sanction is the only source of certainty he has. The supernatural power that a [skeptic] dreads, the unknowable spirit he worships, the consciousness he considers omnipotent, is yours" (Rand 1957: 1044, 1057).

${ }^{24}$ Husserl himself stated plainly, inviting someone like Derrida to take the baton, that his own sense-investigations were not the only paths available to philosophers: "Other paths are possible for sense-investigations with a radical aim" (Husserl [1929] 1969: 7).

${ }^{25}$ Derrida is again taking the baton from Husserl: "For a rational practice, theory a priori can be only a delimiting form; it can only plant fences, the crossing of which indicates absurdity or aberration. What problems arise in this connection for self-education and the education of mankind is a separate question; and, by the way, in its universal form, it is itself a question to be 
dealt with by an all-embracing science, which considers all possibilities and truths" (Husserl [1929] 1969: 6).

${ }^{26}$ The appearance here of the word "natural" is very strange considering Derrida's career-long rejection of all such notions as the "natural" or the "given." For example: "To account for a certain stability (by essence always provisional and finite) is precisely not to speak of eternity or of absolute solidity; it is to take into account a historicity, a nonnaturalness, of ethics, of politics, of institutionality, etc. ... I say that there is no stability that is absolute, eternal, intangible, natural, etc." (Derrida [1988] 1988: 151, my emphases). According to Derrida's own claim that "coherence in contradiction expresses the force of a desire" (Derrida [1966] 2001: 352), this contradiction expresses the force of Derrida's desire for necessary inexpressiveness and constitutive communicative failure (about which I will have more to say in what follows). Additionally, while Derrida's conception of philological/etymological investigation has a distinct Wittgensteinian ring to it, deconstruction, rather than a mere species of grammatical investigation, is, if anything, a perversion. For corroboration of this claim, see Cavell ([1983, 1984, 1986b] 1988, 1985, 1989) and Toril Moi (2009).

${ }^{27}$ The "logic" of Derrida's critique of the metaphysics of presence is most clearly articulated in Of Grammatology ([1967] 1997), in which Derrida explores the work of Saussure and JeanJacques Rousseau and in the process asserts the (paradoxically foundational) importance of such concepts as the supplement and the trace, and "Ousia and Grarnmë: Note on a Note from Being and Time" ([1968] 1982), in which Derrida explores the work of Aristotle and Martin Heidegger and in the process asserts the (paradoxically foundational) importance of such concepts as absence and différance. Its affront to logic, meanwhile, is discernible in Derrida's reliance (inherited from Heidegger) on a "vulgar variant" of concept stealing Rand refers to as the 
reification of the zero: "Observe the fact that in the writings of every school of mysticism and irrationalism, amidst all the ponderously unintelligible verbiage of obfuscations, rationalizations, and equivocations (which include protestations of fidelity to reason and claims to some 'higher' form of rationality), one finds, sooner or later, a clear, simple, explicit denial of the validity (of the metaphysical or ontological status) of axiomatic concepts, most frequently of 'identity' ... You do not have to guess, infer, or interpret. They tell you. But what you do have to know is the full meaning, implications, and consequences of such denials ... One of the consequences (a vulgar variant of concept stealing, prevalent among avowed mystics and irrationalists) is a fallacy I call the reification of the zero. It consists of regarding 'nothing' as a thing, as a special, different kind of existent. (For example, see Existentialism.) This fallacy breeds such symptoms as the notion that presence and absence, or being and non-being, are metaphysical forces of equal power" (Rand [1966-1967] 1990: 60).

${ }^{28}$ In his introduction to "The Origin of Geometry," Derrida incoherently refers to Husserlian epistemology as a "secondary grounding" (Derrida [1962] 1989: 54). I say "incoherently refers" because grounding is epistemologically irreducible. Grounding is an action performed in and by a human consciousness in response to the objective, external world. Derrida seems to think that the (allegedly illusory notion of an) objective, external world is itself some sort of mystical "grounding" rather than the ground on which a human being grounds himself.

${ }^{29}$ Consider the penultimate sentence in Speech and Phenomena: "Contrary to what phenomenology - which is always phenomenology of perception - has tried to make us believe, contrary to what our desire cannot fail to be tempted into believing, the thing itself always escapes" (Derrida [1967] 1973: 104). The only actual attention Derrida gives to the significance in Husserl's work of the primacy of existence comes in the form of two footnotes in his 
introduction to "The Origin of Geometry" (Derrida [1962] 1989: 83-85) wherein he casually dismisses the primacy of existence - having already come to the conclusion that "delay is the philosophical absolute" (Derrida [1962] 1989: 152) and that "the Absolute is present only in being deferred-delayed" (Derrida [1962] 1989: 153) - as an allegedly untenable reduction of the ontologically constitutive "relativity" supported by his nonsensical metaphysics of différance (Derrida [1962] 1989: 84; see also Derrida [1968b] 1973).

${ }^{30}$ Allan Casebier adds that "it is characteristic of the Husserlian system that consciousness is always consciousness of something" (Casebier 1991: 15). Compare these remarks to the Objectivist position according to which "you can become aware of the fact that you are conscious" only "after you have become conscious of something," that only after this point of cultivation can a person then "identify the fact that it is some function in [his or her] mind that is performing this process of awareness" (Rand [1966-1967] 1990: 246). For Derrida, the very idea of an ontological "ground" - let alone an intelligible ontological ground accessible to consciousness - is anathema to his Kantian sensibility. He thus rejects the Husserlian notion of “original self-evidence" (Husserl [1939] 1970: 365) and, indeed, rejects axiomatic concepts tout court. As he puts it in his introduction to "The Origin of Geometry": "Axiomatics in general (from which alone every ideal of exhaustive and exact deductivity can take its sense, from which alone every problem of decidability can then spring) already supposes" a "primordial evidence, a radical ground which is already past" (Derrida [1962] 1989: 55).

${ }^{31}$ Husserl frames his relationship with Descartes in the following manner: "In recent times, the longing for a fully alive philosophy has led to many a renaissance. Must not the only fruitful renaissance be the one that reawakens the impulse of the Cartesian Meditations: not to adopt their content but, in not doing so, to renew with greater intensity the radicalness of their spirit, 
the radicalness of self-responsibility ... Must not the demand for a philosophy aiming at the ultimate conceivable freedom from prejudice, shaping itself with actual autonomy according to ultimate evidences it has itself produced, and therefore absolutely self-responsible - must not this demand, instead of being excessive, be part of the fundamental sense of genuine philosophy?" (Husserl [1931] 1960: 6).

${ }^{32}$ Interestingly, for as much as Derrida was influenced by Nietzsche's critique of the self, his nihilistic tendencies are fundamentally opposed to Nietzsche's hedonism and place him closer to the nihilistic philosophy of Arthur Schopenhauer. The relationship between Nietzsche and Schopenhauer is complex to say the least (for useful overviews of the complexities of their relationship, see, among many others, Grace Neal Dolson [1901] and Steven Bond [2006]). Initially devoted to Schopenhauer's teachings (Nietzsche [1874] 1997: 125-194), Nietzsche ultimately repudiated Schopenhauer for his inability to conquer nihilism (Nietzsche [1883-1888] 1968: 7-82). Even though (as Rand herself observed) Nietzsche's solution to nihilism in the form of hedonism is merely the other side of the same problematic coin (Rand 1964: 10), his critique of nihilism is a well-intentioned plea to embrace not just a will to power but a will to life. For Schopenhauer, meanwhile, consider as exemplary of his nihilism the following sentiments as expressed in The World as Will and Representation: "Whatever one may say, the happiest moment of the happy man is the moment of his falling asleep, and the unhappiest moment of the unhappy that of his awaking ... [Consciousness] would rather have soon made the calculation that the business did not cover the cost, for such a mighty effort and struggle with the straining of all the powers, under constant care, anxiety, and want, and with the inevitable destruction of every individual life, finds no compensation in the ephemeral existence itself, which is so obtained, and which passes into nothing in our hands ... Accordingly, existence is certainly to be 
regarded as an error or mistake, to return from which is salvation" (Schopenhauer [1819] 1966: 578-579, 605). While I believe this connection between Derrida and Schopenhauer is valid and salient, it is to Derrida's credit that, for all of his nihilistic tendencies, he never truly acquiesces to nihilism and instead retains throughout his career a certain Nietzschean will to life.

${ }^{33}$ For background on and analysis of this early point in Derrida's career, see Derrida ([1980] 1983) and Miller (2001).

${ }^{34}$ The following is arguably Derrida's most explicit rehearsal of the "question" of the author conceived of as the "origin" of meaning: "The play [of the chain of signification] seems systematic. But the system here is not, simply, that of the intentions of an author ... the system is not primarily that of what someone meant-to-say ... These communications or corridors of meaning can sometimes be declared or clarified [by the author] ... Then again, in other cases, [the author] can not see the links, can leave them in the shadow or break them up. And yet these links go on working of themselves. In spite of him? Thanks to him? In his text? Outside his text? But then where? Between his text and the language? For what reader? At what moment? To answer such questions in principle and in general will seem impossible; and that will give us the suspicion that there is some malformation in the question itself" (Derrida [1972] 1981: 95-96). ${ }^{35}$ The fact that the antipathy to the concept of structure exemplified by Derrida's critique of Lévi-Strauss has structured poststructuralism ever since is one of the many instances where such anti-foundationalist thinking proves self-defeating. As Wittgenstein averred: "The game of doubting itself presupposes certainty" (Wittgenstein [1951] 1969: 18e) inasmuch as "the questions that we raise and our doubts depend on the fact that some propositions are exempt from doubt, are as it were like hinges on which those turn" (Wittgenstein [1951] 1969: 44e). For 
a more elaborate consideration of this paradox in relation to poststructuralism in particular, see Andrew Britton ([1988] 2009).

${ }^{36}$ Derrida's derision takes the form of a parody of the Declaration of Independence: "We presuppose [The Trial], which we hold to be unique and self-identical, to exist as an original version ... [which] constitutes the ultimate reference for what might be called the legal personality of the text, its identity, its unicity, its rights, and so on" (Derrida [1982] 1992: 185). ${ }^{37}$ Derrida's lengthy engagement with Lacan can essentially be split into two halves. In the first half, Derrida seeks to bring to light Lacan's analytical blindspot. According to Derrida, this blindspot was inherited from Freud and the dubious practice of "applied psychoanalysis" whereby art "is brought into an illustrative position: 'to illustrate' here meaning to read the general law in the example, to make clear the meaning of a law or of a truth" (Derrida [1972] 1987: 425-426), which, Derrida charges, merely results in the critic-as-analyst "anticipating the truth of the text" and thereby denuding the artwork of its original "semantic material" (Derrida [1972] 1987: 415). In the second half, having demonstrated how and where Lacan's analysis was lacking, Derrida sets out to demonstrate and analyze "the recurrence of certain motifs" (such as "the letter hanging under the mantel of the fireplace," which Derrida indicates "has its equivalent in 'The Murders in the Rue Morgue' [1841]") in order to better understand "The Purloined Letter" both as a unique artwork unto itself, with its own structuring principles, and as part of a “textual network" within Poe's oeuvre (Derrida [1972] 1987: 458).

${ }^{38}$ The infamous clash between Derrida and Searle originated with Searle's response (Searle 1977) to Derrida's critique of Austin (Derrida [1972] 1988), which in turn elicited a borderline hysterical response from Derrida (Derrida [1977] 1988). Subsequent to this initial battle, they each continued to occasionally and obliquely critique the other (Searle 1983, 2000; Derrida 
[1988] 1988). In what follows, I will limit my focus to the ramifications of Derrida's incoherence regarding the concept of intention. For more comprehensive contextualization/analysis of the terms, stakes, and consequences of this clash, both in relation to Derrida and Searle in particular and to deconstruction and ordinary language philosophy more broadly, see, among the many commentaries, Jonathan Culler (1982), Christopher Norris (1990), Cavell (1994), Gordon C.F. Bearn (1995, 1998), Stephen Mulhall (2001), Leslie Hill (2007), Michael J. Golec (2009), Moi (2009), Raoul Moati ([2009] 2014), and Judith Wolfe (2013).

${ }^{39}$ Derrida's conception of "fully conscious" intention begs a number of questions. For example: "Fully" conscious as opposed to what? What is the concept of consciousness with which Derrida is working that it makes sensible the postulation of states such as "fully" conscious, "primarily" conscious, "slightly" conscious, etc.? What are Derrida's criteria for determining a given state of consciousness? How often does consciousness "shift" states? How does Derrida explain such shifts? Perhaps as a preemptive measure against such questioning, Derrida introduces, over the course of his dealings with Austin and the concepts of intention and meaning presupposed by ordinary language philosophy, the "supplement" of a "structural unconscious," which he describes as "alien" to and "incompatible with" conscious intention (Derrida [1977] 1988: 73). Even if, for the sake of argument, the existence of a structural unconscious is conceded, does not the existence of an "alien" entity pulling the strings of consciousness preclude such ethical haranguing as that to which Derrida subjects Searle? For a more sensible conception of consciousness, see Rand's articulation of what she refers to as a "screen of vision" (Rand [1958] 2000: 1-9).

${ }^{40}$ In his introduction to "The Origin of Geometry," Derrida describes his fledgling philosophical method of deconstruction as the means by which to avoid in philosophical practice "aberration, 
forgetfulness, and irresponsibility" (Derrida [1962] 1989: 52). However, in light of his fantasy of necessary inexpressiveness (and once again highlighting the relevance of Derrida's own point about the implications of "coherence in contradiction" to the practice of deconstruction itself), is Derrida's pathological fear throughout his career of "aberration, forgetfulness, and irresponsibility" not already a rejection of the claim that we are fated "to mean (to say) something that is (already, always, also) other than what we mean (to say)"? ${ }^{41}$ In "Force and Signification," Derrida asks if it is possible for meaning to "come forth" if not "animated" by an intentionality, or animated by an intentionality which "does not necessarily and primarily belong to a consciousness" (Derrida [1964] 2001: 31). If one were to assess deconstruction as if Derrida believed it was possible - as supported, for example, by his critique of Lévi-Strauss - then Derrida's critique of Rousset and his rejection of the idealization of the artistic object denuded of its "internal historicity" and "subjective origin" contradicts the terms of his own fantasy; if, however, one were to assess deconstruction as if Derrida believed it was not possible - as supported, for example, by his critique of Lacan - then Derrida's reading of The Trial contradicts the terms of his own methodology.

${ }^{42}$ The troubling fact that Culler frames his landmark text on deconstruction according to the terms of Barthes' hedonistic aesthetics clearly indicates that Culler was reading Derrida on Barthesian terms rather than on Derrida's own terms and thus explains, in part, his distortion of deconstruction (Culler 1982: 31). Derrida himself claimed an undying "love for philosophy" (Derrida [1988] 1988: 122) and insisted on an "ethics of discussion" committed to the canons of logic, to "proof, discussion, and exchange" (Derrida [1988] 1988: 157) in the quest for "truth"concepts which Derrida states unequivocally he never sought to "put into question" in the sense 
of contesting their objective existence in the world or their importance to human existence (Derrida [1988] 1988: 150).

${ }^{43}$ Additionally, the anarchic implication of Culler's cartoonish characterization of deconstruction is that, in defiance of logic and reality, one can say and do whatever one wishes. Derrida, however, stressed that this was not his goal with deconstruction: "I have never accepted saying, or encouraging others to say, just anything at all, nor have I argued for indeterminacy as such ... What has always interested me the most, what has always seemed to me the most rigorous ... is not indeterminacy in itself, but the strictest possible determination[s] (Derrida [1988] 1988: 144145).

\section{REFERENCES}

Aristotle. [350 BC] 1995. The Complete Works of Aristotle. Edited by Jonathan Barnes. Princeton: Princeton University Press.

Austin, J.L. 1962. Sense and Sensibilia. Edited by G.J. Warnock. Oxford: Oxford University Press.

Barthes, Roland. [1953] 2012. Writing Degree Zero. Translated by Annette Lavers and Colin Smith. New York: Hill and Wang. . [1966] 2007. Criticism and Truth. Edited and translated by Katrine Pilcher Keuneman. London: Continuum. 
. [1967] 1977. "The Death of the Author." In Image-Music-Text, 142-48. Translated by

Stephen Heath. New York: Hill and Wang.

—_. [1970] 1977. "The Third Meaning: Research Notes on Some Eisenstein Stills." In ImageMusic-Text, 52-68.

_. [1971] 1998. "Responses: Interview with Tel Quel." In The Tel Quel Reader, 249-268.

London: Routledge.

—_. [1971] 1977. “From Work to Text.” In Image-Music-Text, 155-64.

_ _ [1973] 1975. The Pleasure of the Text. Translated by Richard Miller. New York: Hill and Wang.

Beardsley, Monroe C. and W.K. Wimsatt, Jr. 1946. "The Intentional Fallacy.” The Sewanee Review Vol. 54, No. 3: 468-88.

Bearn, Gordon C.F. 1995. "Derrida Dry: Iterating Iterability Analytically.” Diacritics Vol. 25, No. 3 (Autumn): 2-25.

1998. "Sounding Serious: Cavell and Derrida." Representations 63 (Summer): 65-92. 
Benjamin, Walter. [1927-1940] 1999. The Arcades Project. Edited by Rolf Tiedemann. Translated by Howard Eiland and Kevin McLaughlin. Cambridge, MA: Harvard University Press.

Bissell, Roger E. 2002. “A Neglected Source for Rand's Aesthetics.” The Journal of Ayn Rand Studies Vol. 4, No. 1 (Fall): 187-204.

— 2004. "Art as Microcosm: The Real Meaning of the Objectivist Concept of Art." The Journal of Ayn Rand Studies Vol. 5, No. 2 (Spring): 307-63.

Bond, Steven. 2006. “Nietzsche's Critique of Schopenhauer's Vicious Circle.” Minerva 10: 197214.

Bordwell, David and Noël Carroll. 1996. "Introduction.” In Post-Theory: Reconstructing Film Studies, xiii-xvii. Edited by David Bordwell and Noël Carroll. Madison, WI: University of Wisconsin Press.

Bowman, Paul. 2007. Post-Marxism versus Cultural Studies: Theory, Politics, and Intervention. Edinburgh: Edinburgh University Press.

—. 2013. Reading Rey Chow: Visuality, Postcoloniality, Ethnicity, Sexuality. New York: Peter Lang.

-2017. Mythologies of Martial Arts. London: Rowman \& Littlefield International. 
Britton, Andrew. [1988] 2009. "The Myth of Postmodernism: The Bourgeois Intelligentsia in the Age of Reagan." In Britton on Film: The Complete Film Criticism of Andrew Britton, 468-96. Edited by Barry Keith Grant. Detroit: Wayne State University Press.

Carroll, Noël. 1988. Mystifying Movies: Fads and Fallacies in Contemporary Film Theory. New York: Columbia University Press.

Casebier, Allan. 1991. Film and Phenomenology: Toward a Realist Theory of Cinematic Representation. Cambridge: Cambridge University Press.

Cavell, Stanley. [1969] 2002. Must We Mean What We Say? Cambridge: Cambridge University Press.

- [1971] 1979. The World Viewed: Reflections on the Ontology of Film. Cambridge, MA: Harvard University Press.

-1979. The Claim of Reason: Wittgenstein, Skepticism, Morality, and Tragedy. Oxford: Oxford University Press.

- 1981. Pursuits of Happiness: The Hollywood Comedy of Remarriage. Cambridge, MA: Harvard University Press. 
_ [1983] 1988. "The Philosopher in American Life (Toward Thoreau and Emerson).” In In Quest of the Ordinary: Lines of Skepticism and Romanticism, 3-26. Chicago: University of Chicago Press.

—. [1984] 1988. "Being Odd, Getting Even (Descartes, Emerson, Poe).” In In Quest of the Ordinary, 105-49.

—. 1985. "The Division of Talent." Critical Inquiry Vol. 11, No. 4 (June): 519-38.

—. [1986a] 1988. "Texts of Recovery (Coleridge, Wordsworth, Heidegger...)." In In Quest of the Ordinary, 50-75.

—. [1986b] 1988. “The Uncanniness of the Ordinary.” In In Quest of the Ordinary, 153-78.

- 1989. This New Yet Unapproachable America. Chicago: University of Chicago Press.

— 1994. A Pitch of Philosophy: Autobiographical Exercises. Cambridge, MA: Harvard University Press.

Cox, Stephen. 2000. "Review - The Art of Fiction." The Journal of Ayn Rand Studies Vol. 1, No. 2 (Spring): 313-31. 
2004. “Completing Rand's Literary Theory.” The Journal of Ayn Rand Studies Vol. 6, No. 1 (Fall): 67-89.

Critchley, Simon. [1992] 2014. The Ethics of Deconstruction: Derrida and Levinas. Edinburgh: Edinburgh University Press.

—. 2007. "Foreword: Why Žižek Must Be Defended." In The Truth of Žižek, xi-xvi. Edited by Paul Bowman and Richard Stamp. London: Continuum.

Culler, Jonathan. 1982. On Deconstruction: Theory and Criticism after Structuralism. Ithaca, NY: Cornell University Press.

de Man, Paul. [1960] 1984. "Intentional Structure of the Romantic Image." In The Rhetoric of Romanticism, 1-17. New York: Columbia University Press.

Derrida, Jacques. [1959] 2001. “'Genesis and Structure' and Phenomenology,” In Writing and Difference, 193-211. Translated by Alan Bass. Chicago: University of Chicago Press.

— . [1962] 1989. "Introduction to The Origin of Geometry." In Edmund Husserl's Origin of Geometry: An Introduction, 25-153. Translated by John P. Leavey, Jr. Lincoln, NE: University of Nebraska Press.

—_. [1964] 2001. "Force and Signification." In Writing and Difference, 1-35. 
—. [1966] 2001. "Structure, Sign, and Play in the Discourse of the Human Sciences." In Writing and Difference, 351-70.

- [1967] 1973. Speech and Phenomena and Other Essays on Husserl's Theory of Signs.

Translated by David B. Allison. Evanston, IL: Northwestern University Press.

- [1967] 1997. Of Grammatology. Translated by Gayatri Chakravorty Spivak. Baltimore, MD: Johns Hopkins University Press.

—. [1968a] 1982. "Ousia and Grammè: Note on a Note from Being and Time." In Margins of Philosophy, 29-67. Translated by Alan Bass. Chicago: University of Chicago Press.

—. [1968b] 1982. “Différance.” In Margins of Philosophy, 1-27.

—. [1972] 1981. Dissemination. Translated by Barbara Johnson. Chicago: University of Chicago Press.

—. [1972] 1987. "Le facteur de la vérité." In The Post Card: From Socrates to Freud and Beyond. Translated by Alan Bass. Chicago: University of Chicago Press.

—. [1972] 1988. "Signature Event Context.” In Limited Inc., 1-23. Edited by Gerald Graff. Evanston, IL: Northwestern University Press. 
—. [1977] 1988. “Limited Inc. a b c...” In Limited Inc., 29-110.

—. [1980] 1983. "The Time of a Thesis: Punctuations." In Philosophy in France Today. Edited by Alan Montefiore. Cambridge: Cambridge University Press.

—. [1982] 1992. "Before the Law." In Acts of Literature, 183-220. Edited by Derek Attridge. Chicago: University of Chicago Press.

—. [1988] 1988. “Toward an Ethic of Discussion.” In Limited Inc., 111-60.

—. [1989] 1992. “'This Strange Institution Called Literature': An Interview with Jacques Derrida." In Acts of Literature, 33-75.

—. 2004. "I Am At War with Myself." SV (November): 1-13.

Dolson, Grace Neal. 1901. "The Influence of Schopenhauer upon Friedrich Nietzsche." Philosophical Review Vol. 10, No. 3: 241-50.

Fink, Bruce. 1995. The Lacanian Subject: Between Language and Jouissance. Princeton, NJ: Princeton University Press. 
Freud, Sigmund. [1937] 1939. Moses and Monotheism. Translated by Katherine Jones. London: Hogarth Press.

Golec, Michael J. 2009. “'The Thinking Man's Filter': J. L. Austin's Ordinary Language Philosophy as Cultural Criticism." Cultural Critique 72 (Spring): 66-88.

Gotthelf, Allan. 2000. On Ayn Rand. Belmont, CA: Wadsworth.

Hawkes, Terence. 1977. Structuralism and Semiotics. Berkeley, CA: University of California Press.

Heath, Stephen. 1973. "Comment on 'The Idea of Authorship." Screen Vol. 14, No. 3 (Autumn): $86-91$. 1975a. "Film and System: Terms of Analysis Part I." Screen Vol. 16, No. 1 (Spring): 777. 1975b. "Film and System: Terms of Analysis Part II." Screen Vol. 16, No. 2 (Summer): $91-113$.

Hill, Leslie. 2007. The Cambridge Introduction to Jacques Derrida. Cambridge: Cambridge University Press. 
Hirsch, E.D. 1967. Validity in Interpretation. New Haven, CT: Yale University Press.

Husserl, Edmund. [1929] 1969. Formal and Transcendental Logic. Translated by Dorion Cairns. The Hague: Martinus Nijhoff.

—. [1931] 1960. Cartesian Meditations: An Introduction to Phenomenology. Translated by Dorion Cairns. The Hague: Martinus Nijhoff.

- [1939] 1970. The Crisis of European Sciences and Transcendental Phenomenology: An Introduction to Phenomenological Philosophy. Translated by David Carr. Evanston, IL: Northwestern University Press.

—. [1948] 1973. Experience and Judgment: Investigations in a Genealogy of Logic. Revised and edited by Ludwig Landgrebe. Translated by James S. Churchill and Karl Ameriks. London: Routledge.

Kelley, David. [1990] 2000. The Contested Legacy of Ayn Rand: Truth and Toleration in Objectivism. New Brunswick, NJ: Transaction.

Lacan, Jacques. [1953] 2006. "The Function and Field of Speech and Language in Psychoanalysis." In Écrits, 197-268. Translated by Bruce Fink. New York: W.W. Norton. 
_ [1954-1955] 1991. The Seminar of Jacques Lacan - Book II: The Ego in Freud's Theory and in the Technique of Psychoanalysis, 1954-1955. Translated by Sylvana Tomaselli. New York: W.W. Norton.

—_. [1955] 2006. “Seminar on “The Purloined Letter.”' In Écrits, 6-48.

—. [1957] 2006. “The Instance of the Letter, or Reason Since Freud.” In Écrits, 412-41.

—. [1958] 2006. “The Youth of Gide, or the Letter and Desire.” In Écrits, 623-44.

—_ [1972] 1998. The Seminar of Jacques Lacan - Book XX: Encore: On Feminine Sexuality, The Limits of Love, and Knowledge. Translated by Bruce Fink. New York: W.W. Norton.

Miller, J. Hillis. 1998. Reading Narrative. Norman, OK: Oklahoma University Press.

—. 2001. "Derrida and Literature." In Jacques Derrida and the Humanities: A Critical Reader, 58-81. Edited by Tom Cohen. Cambridge: Cambridge University Press.

Minsaas, Kirsti. 2000. "The Role of Tragedy in Ayn Rand's Fiction." The Journal of Ayn Rand Studies Vol. 1, No. 2 (Spring): 171-209.

—. 2004. "The Poetics of Admiration: Ayn Rand and the Art of Heroic Fiction." The Journal of Ayn Rand Studies Vol. 6, No. 1 (Fall): 153-83. 
—. 2005. "Mimesis and Expression in Ayn Rand's Theory of Art." The Journal of Ayn Rand Studies Vol. 7, No. 1 (Fall): 19-56.

—. 2007. "Ayn Rand's Recasting of Ancient Myths in Atlas Shrugged." In Ayn Rand's Atlas Shrugged: A Philosophical and Literary Companion, 131-40. Edited by Edward W. Younkins. Burlington, VT: Ashgate.

Moati, Raoul. [2009] 2014. Derrida/Searle: Deconstruction and Ordinary Language. Translated by Timothy Attanucci and Maureen Chun. New York: Columbia University Press.

Moi, Toril. 2009. “"They Practice their Trades in Different Worlds': Concepts in Poststructuralism and Ordinary Language Philosophy." New Literary History Vol. 40, No. 4 (Autumn): 801-24.

Mowitt, John. 1992. Text: The Genealogy of an Antidisciplinary Object. Durham, NC: Duke University Press.

Mulhall, Stephen. 2001. "Deconstruction and the Ordinary." In The Legacy of Wittgenstein: Pragmatism or Deconstruction, 75-92. Edited by Ludwig Nagl and Chantal Mouffe. New York: Peter Lang.

Narboni, Jean. [1970] 1990. “Vicarious Power.” In Cahiers du Cinéma - 1969-1972: The Politics of Representation, 150-62. Edited by Nick Browne. London: Routledge. 
Nietzsche, Friedrich. [1874] 1997. “Schopenhauer as Educator.” In Untimely Meditations, 125-94. Edited by Daniel Breazeale. Translated by R.J. Hollingdale. Cambridge: Cambridge University Press.

- [1883-1888] 1968. The Will to Power. Edited by Walter Kaufmann. Translated by Kaufmann and R.J. Hollingdale. New York: Vintage.

Norris, Christopher. 1990. "Review - Limited Think: How Not to Read Derrida.” Diacritics Vol. 20, No. 1 (Spring): 16-36.

Peikoff, Leonard. 1991. Objectivism: The Philosophy of Ayn Rand. New York: Meridian.

—. [1981] 1993. “An Exercise in Philosophical Detection.” In The Objectivist Forum, 12-15. Edited by Harry Binswanger. New York: TOF.

Prince, Stephen. 1992. "Review - Mystifying Movies: Fads and Fallacies in Contemporary Film Theory." Film Quarterly Vol. 45, No. 2 (Winter): 49-51.

Rand, Ayn. [1943] 1995. "Letter to Archibald Ogden." In Letters of Ayn Rand, 87-90. Edited by Michael S. Berliner. New York: Plume. [1943] 1996. The Fountainhead. New York: Signet. 
—. 1957. Atlas Shrugged. New York: Random House.

. [1958] 2000. The Art of Fiction. Edited by Tore Boeckmann. New York: Plume.

. 1961. For the New Intellectual: The Philosophy of Ayn Rand. New York: Signet.

- 1962. “Choose Your Issues.” The Objectivist Newsletter Vol. 1, No. 1 (January):

—. 1964. The Virtue of Selfishness: A New Concept of Egoism. New York: Signet.

_ [1966] 1970. Capitalism: The Unknown Ideal. New York: Signet.

—. [1966] 1989. "Altruism as Appeasement." In The Voice of Reason: Essays in Objectivist Thought, 32-9. Edited by Leonard Peikoff. New York: Meridian.

—. [1966-1967] 1990. Introduction to Objectivist Epistemology. Edited by Harry Binswanger and Leonard Peikoff. New York: Meridian.

_. [1969] 1975. The Romantic Manifesto. New York: Signet.

—. [1973a] 1982. "An Untitled Letter." In Philosophy: Who Needs It, 102-19. Edited by Leonard Peikoff. New York: Signet. 
[1973b] 1982. "The Metaphysical versus the Man-Made." In Philosophy: Who Needs It, 23-34.

—. [1974a] 1982. "Philosophy: Who Needs It.” In Philosophy: Who Needs It, 1-11.

—. [1974b] 1982. "Philosophical Detection.” In Philosophy: Who Needs It, 12-22.

Rivette, Jacques. [1968] 1986. “Time Overflowing.” In Cahiers du Cinéma - 1960-1968: New Wave, New Cinema, Reevaluating Hollywood, 317-23. Edited by Jim Hillier. Cambridge, MA: Harvard University Press.

Rodowick, D.N. [1988] 1994. The Crisis of Political Modernism: Criticism and Ideology in Contemporary Film Criticism. Berkeley, CA: University of California Press.

—. 2013. “The Value of Being Disagreeable.” Critical Inquiry Vol. 39, No.3 (Spring): 592613.

- 2015. Philosophy's Artful Conversation. Cambridge, MA: Harvard University Press.

Saussure, Ferdinand de. [1916] 2011. Course in General Linguistics. Edited by Perry Meisel and Haun Saussy. Translated by Wade Baskin. New York: Columbia University Press. 
Schopenhauer, Arthur. [1819] 1966. The World as Will and Representation. Translated by E.F.J. Payne. New York: Dover.

Searle, John R. 1977. "Reiterating the Differences: A Reply to Derrida.” Glyph 2: 198-208.

—. 1983. "The World Turned Upside Down." The New York Review of Books (October): http://www.nybooks.com/articles/1983/10/27/the-word-turned-upside-down/.

—. 2000. "Reality Principles: An Interview with John R. Searle." Reason (February): http://reason.com/archives/2000/02/01/reality-principles-an-intervie.

Sobchak, Vivian. 1992. The Address of the Eye: A Phenomenology of Film Experience. Princeton, NJ: Princeton University Press.

Torres, Louis and Michelle Marder Kamhi. 2000. What Art Is: The Esthetic Theory of Ayn Rand. Chicago: Open Court.

Weber, Samuel. [1987] 2001. Institution and Interpretation. Stanford, CA: Stanford University Press.

Wittgenstein, Ludwig. [1921] 2001. Tractatus Logico-Philosophicus. Translated by D.F. Pears and B.F. McGuinness. London: Routledge. 
. [1949] 1967. Philosophical Investigations. Edited by G.E.M. Anscombe, R. Rhees, and G.H. von Wright. Translated by Anscombe. Oxford: Blackwell.

—. [1951] 1969. On Certainty. Edited by G.E.M. Anscombe and G.H. von Wright. Translated by Anscombe and Denis Paul. Oxford: Blackwell.

Wolfe, Judith. 2013. “The Ordinary' in Stanley Cavell and Jacques Derrida." Minerva 17: 25068.

Wood, Robin. [1988] 2002. “Introduction (1988).” In Hitchcock's Films Revisited, 1-51. New York: Columbia University Press.

Britton, Andrew. [1988] 2009. "The Myth of Postmodernism: The Bourgeois Intelligentsia in the Age of Reagan." In Britton on Film: The Complete Film Criticism of Andrew Britton, 468-96. Edited by Barry Keith Grant. Detroit: Wayne State University Press.

Žižek, Slavoj. 2012. Less than Nothing: Hegel and the Shadow of Dialectical Materialism. London: Verso. 